\title{
A Comparison of Human Resource Strategies between the Manufacturing and the Service Sector of Japanese Companies in China
}

\author{
Lau Chung Ming
}

Correspondence: Lau Chung Ming, Japan.

Received: April 8, 2018

doi:10.11114/bms.v4i2.3312
Accepted: May 22, $2018 \quad$ Online Published: May 27, 2018

URL: https://doi.org/10.11114/bms.v4i2.3312

\begin{abstract}
An investigation into how Japanese multinational corporations (MNCs) manage their overseas HRM practices affiliates and an exploration of the underlying factors affecting each practice could contribute to enhancing business knowledge and practice. This is especially important when taking into consideration the dramatic change in industry structure and business environment in China. This study adopted a quantitative survey method and analyzed 180 responses from employees of Japanese companies in China (JCCs); 113 from Mainland China and 67 from Hong Kong. Performance appraisal was rated the most important concern of the five human resource management (HRM) practices. Corporate policy and the complexity of the business were the main factors affecting decision for expatriation from the viewpoint of headquarters and locals, respectively. Minor differences were observed in HRM practices in the manufacturing and the service sector, and location, age, and size of the companies.
\end{abstract}

Keywords: global HRM, Japanese MNCs, manufacturing sector service sector, mainland China, Hong Kong

\section{Introduction}

A number of factors that include sheer size of the labor pool, the market and growth prospects; have induced an influx of Foreign Direct Investment (FDI) into China. In the past 30 years, the manufacturing sector has contributed immensely to the growth of China's economy. However, China is losing its status as the "World's Factory", and investors are shifting their production bases to other developing countries in search of cheaper labor costs. Several government reports have also shown that due to over-capacity in the manufacturing sector, most industries have excess outputs and inventories (Wang, 2014). Despite years of economic growth, there is limited expansion in the service industries like the medical, finance, logistics and public service industries. Hence, the government of China has recently prioritized the acceleration of development in the service industry (tertiary industries). Obviously, a change in the business environment in China is inevitable.

Japan has a huge FDI in China; therefore, these foreseeable changes pose a threat to Japanese Multinational Corporations (MNCs) operating in China. The IMD World Competitiveness Yearbook and Fortune Global 500 also show that Japan's rank in competitiveness had recently dropped. This has been attributed in part to an ineffective global human resource (HR) strategy (Stewart and Morrison, 2010). These include over-reliance on expatriates from headquarters and conventional Japanese management styles by global Japanese MNCs. Therefore, Japanese MNCs should attempt to find solutions to avert this challenge in their overseas business locations.

Previous studies on human resource management (HRM) practices have been conducted in a general manner (Bartlett \& Yoshihara, 1988; Beechler et al., 1993). They have compared the differences in HRM strategies between industries, e.g. manufacturing and service industries. However, HRM is more critical to the service sector since a company's assets are intangible (Wickramasinghe \& Fonseka ,2012). Thus, it is important to compare the underlying differences between HRM Strategies in the manufacturing and service sector from a global perspective.

The objective of this paper is to compare the difference in human resource (HR) strategies of Japanese companies in China, with respect to expatriation, between the manufacturing and the service sector, and explore any appropriate global HR considerations to cope with the foreseeable problems in Mainland China. 


\section{Changes of the Business Environment for JCCs}

\subsection{Change of the Business Environment in Mainland China}

Since 1978, FDI inflows into China and investments increased due to economic reform. In 2016, there were 27,900 FDI projects in China valued at USD 126 billion according to data from NBS (2017). Although the number of projects has been decreasing since 1993, the yearly value of FDI has increased about three-fold in the past 20 years. The capital formation rate (percentage of GDP) in China has also shown a continuous increasing trend, (with an adjustment period every few years), due to the government of China executing measures to control continuous growth.

By 2008, the growth ratio had reached $43.8 \%$ and it did not stop and it hit another high record. The latest record achieved was close to 50\%. In addition, a report from International Monetary Fund (IMF) indicated that the overall production capacity utilization in China was about 60\% in 2012 (IMF, 2012). In general, increasing an economy's capital stock also increases its capacity for production; this implies that an economy with higher capital stock can produce more. However, investors became unsure if continuing a high level of investment in China could generate proportional returns. Being cognizant of such risk, the government of China implemented several measures to lessen the atypical economic growth. Although company bankruptcies or unemployment would be experienced during this transitional period due to contract policies, the changes would not be detrimental to the economy in the long run. China needed a better reallocation of its resources to improve its economic efficiency; however this situation has not been alleviated. In principle, therefore it is not surprisingly the growth of China's economy has stagnated occasionally.

There is a directional change in development experienced in the manufacturing sector in China. Currently, most of China's manufacturing industry is at the low-end of the global value chain. It must therefore fight for the "technical advantage" and "brand advantage" at the higher end of the "smiling curve"1 value chain. China should not be satisfied with the role of being the "world's factory"; China ought to speedily move up both ends of the "smiling curve". Currently, most service enterprises in China are comprised of traditional firms like small food companies and small businesses. There is limited contribution from medical, finance, logistic and public service industries.

Recently, the government of China announced new targets and proposed changes for future development in accordance with its continuous reforms and the opening-up policy. One of the targets was to speed up developments in the service industry. In 2012, the turnover tax system was abolished and changed to a value added tax to encourage more investors in the service area and to expedite the development of the service industry. In Sep 2013, China started a new "Free Trade Zone (FTZ)" program and Shanghai was selected as the first zone to pilot this initiative. Within a FTZ, it would be possible for enterprises to enjoy certain tax privileges, freedom of foreign currency exchange with the RMB and considerations in market interest rates for specified service industries. Thus, FTZ would induce more private companies to compete with the traditional state-owned enterprises and improve international competitiveness.

The average wage costs have been increasing in China. The increase in labor cost will accelerate migration to automation in the manufacturing sector from labor-intensive operations. China is densely populated and employment is required to stabilize the society. Thus, the enhancement of employment, instead of "GDP suprematism", will be the main government policy in China.

Figure 1 (NBS, 2017) shows that over the past three decades, the secondary (manufacturing) sector kept a stable ratio of contribution to China's GDP. From early 2010 onward, the composition ratio in the secondary sector was changing and started to reduce sharply, while the tertiary, or service sector had a steadily increasing trend in its contribution to China's GDP. On the other hand, Figure 2 (NBS, 2017) indicates that the change in the number of people employed in the secondary sector of industry dropped compared with previous year since 2013, while the change of number of people employed in the tertiary or service sector has recorded a significant increase during the same period. Both trends indicate the momentous change of these sectors' contribution to China's GDP and related employment.

\footnotetext{
${ }^{1}$ A smiling curve is an illustration of value-adding potentials of different components of the value chain in an IT-related manufacturing industry which was first proposed by Stan Shih, the founder of Acer, an IT company headquartered in Taiwan, around 1992. According to his concept, both ends of the value chain command higher values added to the product than the middle part of the value chain.
} 


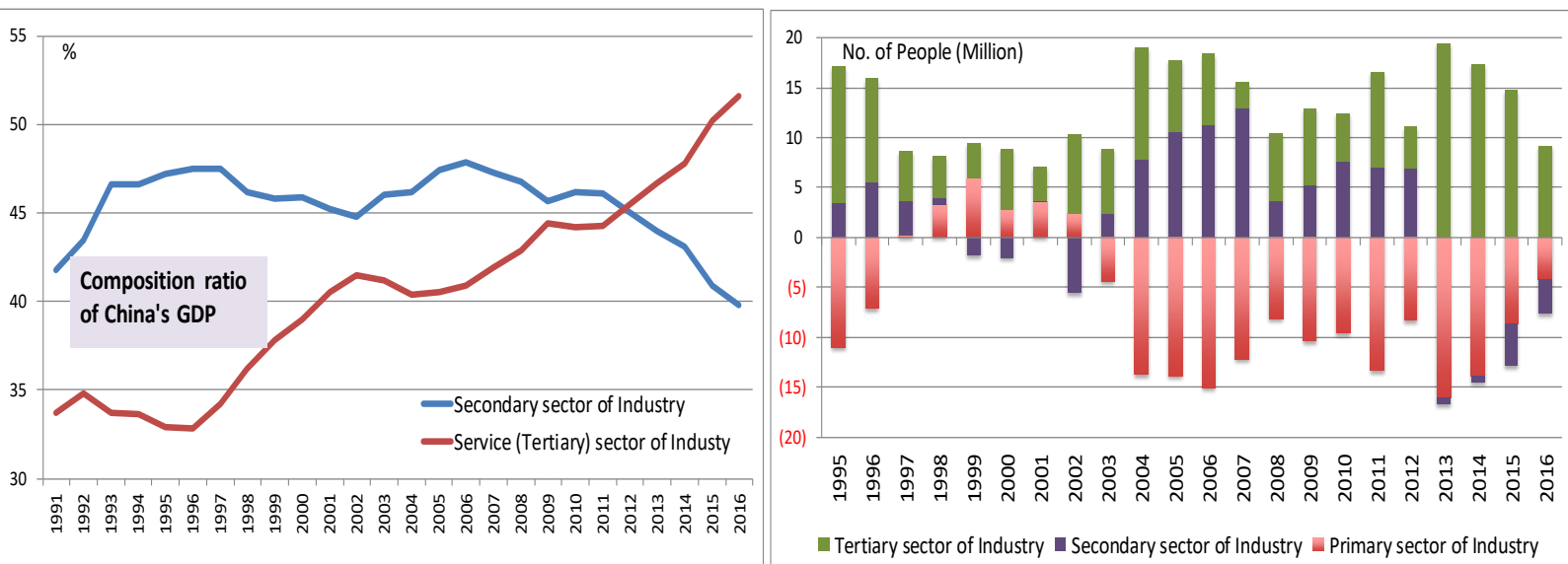

Figure 1. Composition of China's GDP by sector of Industry\& Figure 2. Change of number of people employed by sector of industry

\section{Source: NSB(2017)}

By any standard, China's economic performance over the last three decades has been impressive. There are however indicators that China's recent growth has been moderate, a question is raised whether China can maintain the growth with current pace or will slow down even further. In Table 1, China's GDP growth was predicted to decline gradually from an average 8.5 percent in 2011 to2015 to around 5 percent in 2026 to 2030 (World Bank, 2013).

Table 1. Economic Forecast of China in 2016-2030

\begin{tabular}{|c|c|c|c|c|c|}
\hline (Unit:\%) & $1995-2010$ & $2011-2015$ & $2016-2020$ & $2021-2025$ & $2026-2030$ \\
\hline \multicolumn{6}{|l|}{ GDP Growth rate (Yearly) } \\
\hline Labor Growth & 0.9 & 0.3 & -0.2 & -0.2 & -0.4 \\
\hline \multirow[t]{2}{*}{ Labor Productivity Growth } & $\underline{8.9}$ & $\underline{8.3}$ & $\underline{7.1}$ & $\underline{6.2}$ & $\underline{5.5}$ \\
\hline & 9.9 & 8.6 & 7.0 & 5.9 & 5.0 \\
\hline \multicolumn{6}{|l|}{ Economic Index (End of Year) } \\
\hline Investment/ GDP & 46.4 & 42.0 & 38.0 & 36.0 & 34.0 \\
\hline Consumption/GDP & 48.6 & 56.0 & 60.0 & 63.0 & 66.0 \\
\hline Manufacturing/ GDP & 46.9 & 43.8 & 41.0 & 38.0 & 34.6 \\
\hline Service/ GDP & 43.0 & 47.6 & 51.6 & 56.1 & 61.1 \\
\hline Labor ratio of primary sector of industry & 38.1 & 30.0 & 23.7 & 18.2 & 12.5 \\
\hline Labor ratio of tertiary sector of industry & 34.1 & 42.0 & 47.6 & 52.9 & 59.0 \\
\hline
\end{tabular}

Source: The World Bank (2013)

The slowdown could be attributed to the fact that majority of the growth that was attained from shifting resources from the agricultural sector to the industrial had already occurred. The tertiary or service sector will increasingly influence China's economy in 2020 and beyond. The government will need to provide more intangible public goods and services like systems, regulations, and policies, which increase production efficiency, promote competition, facilitate specialization, enhance the efficiency of resource allocation, protect the environment, and reduce risks and uncertainties; while at the same time rendering relatively fewer "tangible" public goods and services directly.

Emerging market economies will then retain a comparative advantage in the manufacturing sector. In China, an increase in unit cost of labor will further raise the costs of services, hence the overall economic growth will slow down because productivity growth in services is usually slower than in manufacturing (World Bank, 2013).

\subsection{Remarkable Expansion of the Service Sector in Hong Kong}

The government of the Hong Kong's Special Administrative Region adopted an "appropriately proactive" economic strategy. This was done with a view to, creating a business-friendly environment; promoting new industries with growth potential; enhancing the competitiveness of the pillar industries ; developing links with emerging economies; building an international financial center and strengthening its' position as the region's hub for headquarters', trade, logistics, shipping, and tourism ( $\mathrm{Li}$ et al., 2009; Meyer, 2008). As an international financial, trade and shipping center, Hong Kong has always been involved in regional and international economic affairs. Hong Kong's, economic advantages 
include a sound banking system, virtually no public debt, a strong legal system, ample foreign exchange reserves, rigorous anti-corruption measures and close ties with Mainland China. It has the most efficient and corruption-free application procedure, free trading, the lowest income tax and corporate tax as well as sustainable government finance.

In 1997, Hong Kong faced the biggest economic hurdle in its colorful history when Great Britain ended more than 150 years of colonial rule and handed it over to China. Under the "one country, two systems" arrangement, Hong Kong tried to maintain its prosperous economy via retaining its own currency, border checkpoints with China and fiscal independence from Beijing. During this period, Hong Kong's manufacturing sector was restructured; labor-intensive and sophisticated industries were moved, mainly to the neighboring Guangdong Province in China. In the past decade, the service sector in Hong Kong gained greater prominence. In 2016, this sector generated 92.2 per cent of Hong Kong's Gross Domestic Product (GDP). Even after excluding the public sector, services still accounted for about 82 per cent of GDP in 2016. To meet the challenges of rapid technological change and the increasingly intense competition brought about by globalization, the Hong Kong economy has been shifting towards higher value-added services and more knowledge-based activities (Census and Statistics Department, 2017).

In November 2016, a new agreement to govern trade in services between Hong Kong and Mainland China under the framework of the Closer Economic Partnership Arrangement (CEPA) was signed. The new legislation covers concessionary profits tax rate for corporate treasury centers, new deduction rules for interest expenses incurred by intra-group financing businesses, and new profits tax and stamp duty treatments with respect to regulatory capital securities. This new tax regime puts Hong Kong in a competitive position when MNCs wish to set up or relocate their regional treasury centers and their company headquarters in Asia. Hong Kong now steps into a new generation of continuously developing its service sector and promoting global business hubs based-on its past experiences, while Mainland China is growing its service sector. The brilliant performance of Hong Kong's service sector could provide numerous insights to Mainland China for future development. Mainland China has now partially or fully opened up 153 (95.6\%) of the 160 World Trade Organization services trade sectors

\subsection{Japanese MNCs' Competitive Position}

Japan's rank in world competitiveness has worsened in recent years. An ineffective global HR strategy is one of the major reasons for the drop in Japanese companies' global competitive ranking; besides insufficient demand for high quality products, failure of product marketing, and the absence of a long-term business plan (Stewart \& Morrison, 2010). HRM could be regarded as an outcrop of the current interest in corporate and business strategies (Pfeffer, 1994). A growing body of research has argued that there is a causal link between certain HRM practices and a firm's outcomes, such as financial performance and organizational effectiveness (Alfes et al., 2013). The balance between assigning expatriates and deploying locals is still considered a major challenge in global HRM practice (Ulrich et al., 2013). From a global perspective, HR must consider the development of global talent in place deploying people on overseas assignments either as expatriates or temporary teams. Therefore, the staffing strategy of "parent country national (PCN)" vs. "host country national" (HCN) is a key measure of effective global HRM practice (Dessler, 2011). Capable leaders ought to know which aspects of the business to 'globally integrate and standardize' ("global integration") or 'locally adapt and differentiate' ("local responsiveness").

In 2012, US companies and European companies had identified that sub-optimal human resources strategies and how labor turnover was managed as one of five key issues to be addressed in their business operations according to a report from JBIC (2012). However, it is interesting that Japanese companies did not consider the report of the JBIC (2012). It is possible that Japanese companies were not as sensitive to human resource problems as US companies and European companies.

Japanese MNCs have been criticized for over-assignment of PCNs or expatriates in their overseas affiliates. In Japanese companies which are highly hierarchical, serious barriers exist between local managers and Japanese expatriates. This is considered as one of the major obstacles to Japan's global competitive position. Japanese management style is also regarded in some ways to be poorly suited to the working style of the Chinese business environment. Japanese companies rely on employee loyalty, docility and sacrifice in its work culture. However, recent university graduates in China are highly concerned with the possibility of promotion (69.2\%) and remuneration (61.4\%) (Deloitte Shanghai, 2013). Many qualified Chinese employees became frustrated and resigned from their jobs at Japanese-owned companies due to inadequate participation in decision-making processes, limited promotion opportunities (especially for females), and a non-performance based appraisal system ( Ma, 1998; Taylor, 1999; and Jochen,2002).

The localization of the overseas management composition has not been prioritized by Japanese MNCs. In addition, changes in China's business environments have posed a challenge to Japanese MNC in handling the human resources issues and managing their business in China (Wang, 2014). 


\section{Discussion of the Characteristics of JCC's HRM by Industry}

\subsection{Review of Management Characteristics of the Manufacturing Sector and the Service Sector}

Researchers have compared manufacturing and service companies on various aspects, e.g organizational performance (Chu \& Chen, 2007; Goddard et al., 2015; Larsen et al., 2006; and Sengupta et al., 2006). This characterization draws attention to specific aspects that generally distinguish manufacturing companies from service-oriented companies. The main difference between the two is the tangibility of their product - whether the product is produced on demand or for inventory, whether or not customers are actively involved in the production or services, whether operations are labor-intensive or automated, and the timing of consumption of services and products (Bowen \& Schneider, 1988; Jackson \& Schuler, 1995; Wickramasinghe \& Fonseka, 2012). Furthermore, manufacturing is usually a low-customer contact sector, but service provision is a high-customer contact sector.

There are significant differences in HRM practices in service (non-manufacturing) companies compared to manufacturing companies. Due to fundamental differences in manufacturing and service sector, HRM practices should also vary accordingly. In the manufacturing sector, the presence of unions affects HRM practices that include union contract issues and negotiation skills. HRM policies should ensure comfortable employee working conditions like lighting, ventilation, temperature and ambience exist and that occupational health and safety measures are in place. HR practices in manufacturing sector are much more rules-driven and consistent concerning discipline. Communicating with blue-collar employees is not easy and therefore frequent face-to-face meetings are necessary to foster productive relationships with employees.

According to Schneider (1994), there is a significant correlation between employee satisfaction and customer satisfaction. HRM practices of service industries should therefore prioritize customer satisfaction and service excellence as their primary goals. For service companies, a highly-educated workforce, recognition of employee skills and competencies, proximity to the market, unique and personalized service offerings, active customer participation in service development and the capacity to quickly and efficiently respond to the demand for new services are also important features. A measure of job performance should be valid, reliable, practical and free from bias.

On the basis of the human capital theory and system theory perspectives of the relationship between human and technical subsystems, there are differences in hiring, compensation and development practices between advanced technology manufacturing companies and traditional technology manufacturing companies. The structures of manufacturing companies commonly are product, geographical, functional, and matrix organizations, while there are different structures in service companies (Wickramasinghe \& Fonseka, 2012).

According to the study by Beattie \& Smith (2010), absenteeism, remuneration, training budget, and employees differentiated by function were the most internally collated indicators by manufacturing sector companies, while training budget, tracking of training expenditure against budget, absenteeism, remuneration, and employee performance were the most internally collated indicators by service sector's companies (Wickramasinghe \& Fonseka, 2012).

Given that the outcomes are not tangible within the service sector, both academics and practitioners have struggled with measuring productivity from a HRM perspective. Having job performance measured through customer ratings is neither practical nor free from bias, while the job performance measured solely by supervisors or peers does not take into account the customer perspective, as well. Customer satisfaction is a measure of performance for both the service organization and the individual. The service industry should include customer input and employee input in their appraisals with clear metrics and well-design reward systems (Krishnaveni \& Deepa, 2011). Limited focus on offering a probation period to new recruits in service industries is an impediment to their customer centric model. New employees should be trained to focus on customer requirements and customer satisfaction when they are inducted into the organization. (Krishnaveni \& Deepa, 2011)

An efficient strategy systemically manages all HR measures to directly persuade employee thoughts and performance in a way that guides the business to accomplish its competitive strategy (Huang, 2001). It is important for companies to establish HRM practices that suit their business strategies if they want to generate high profits (Taylor, 1999).

\subsection{Hypotheses on the HRM of JCCs}

Based on the review and discussions above, we came up with the following hypotheses, which were examined in this study.

Hypothesis 1: JCCs are more likely to adopt Japanese expatriates to act as top management staff, like the Chief Executive Officer (CEO) or General Manager (GM), regardless of sector (i.e. manufacturing sector or service sector). 
Hypothesis 2: JCCs are likely to have different HRM practices in the manufacturing and the service sector.

Hypothesis 3: JCCs are likely to have differences in making expatriation decisions in the manufacturing and the service sector.

\section{Research Methodology}

Quantitative research methods were used to examine the relationship between different variables in order to understand differences in HRM practices and related factors between the manufacturing and the service sector of JCCs.

\subsection{The Design of Questionnaire}

Using the survey method, a questionnaire was adopted to assess various HRM practices in Japanese companies located in Mainland China and Hong Kong.

During the recent decades, the service sector in Hong Kong has gained greater prominence. Hong Kong was therefore included in the study sample to specifically point out features of HR issues in the service sector that could also apply to Mainland China.

Closed-end questionnaires were sent to 3,730 Japanese companies in China (JCCs) located in Mainland China and Hong Kong.

\subsection{The Dependent Variables}

The dependent variables of this study were drawn from features of HRM of JCCs. To identify the CEOs' country of origin, potential respondents were asked to indicate whether the CEO or GM of the company was Japanese or a local. To assess the degree of importance of five HRM practices, respondents were asked to rank five HRM practices that included recruitment and expatriation, performance appraisal, training and education, labor relations, and compensation and reward by indicating their top three: 1 as the most important, 2 as the second most important, and 3 as the third most important. At first, respondents were asked to identify the importance level by ranking their top three of the five key HRM practices ( 1 as the most important, 2 as the second most important, and 3 as the third most important). By using a traditional grade-point scale, "most important" was scored 3 points, "second most important" 2 points, and "third most important" 1 point. The weighting of priority was taken into consideration during data analysis.

Regarding expatriation, several factors that were used to assess this were categorized into two: "from headquarters' point of view" including availability of talents, technical gap, experience of global business, investment style, performance contribution to $\mathrm{HQ}$, localization promotion, and corporate policy, and "from overseas affiliate's point of view" including availability of local talents, locational advantage, local operation risk, size of company, complexity of business, and years of business operation.

The respondents were asked to rank the top three important factors affecting expatriation decisions including overseas management experience, own skills and knowledge, handling skills of culture difference, and capability of language by indicating 1 as the most important, 2 as the second most important, and 3 as the third most important in each category.

\subsection{The Explanatory Variables}

Four company attributes: industry sector, age, size, and location were included as explanatory variables to verify the differences in HRM practices between various JCCs.

(1) Industry attributes

Although this analysis was focused on the difference between JCCs in the manufacturing and the service sector, additional verification that included a detailed specific industry analysis was used to provide extra insight. The Industry was identified by a single item selected from a list of 20 possible choices, including automobiles, electric machines, trading, finance, logistic, and so on, which were later grouped into the manufacturing and the service category.

(2) Age of JCC

With time, overseas subsidiaries gradually accumulate operational experience, become familiar with operations, decrease the anxiety associated with overseas operations, and reduce the impact of environmental risks. Therefore, an organization's life cycle can have a direct effect on its' HRM practices. Other factors held constant, the duration of overseas operation would have an influence on the tendency to localization, decision of expatriation, or implementation of each HRM practice of the JCC.

(3) Company size of JCC (number of employees)

A Japanese MNC company's size is an indication of its investment scale in an overseas operation; it indirectly reflects the contribution of revenue by the parent company in Japan. Larger overseas companies are considered 
more important to their parent companies than smaller overseas companies. In addition, the focus of HRM varies according to the size of company. For example, labor relations are more important when the number of employees increases.

(4) Locational factor

This has direct impact on the management style of overseas operations. Access to local human resource, availability of capable talents, and the availability of transport infrastructure are considered to have an impact on business operations. If a company can actively and easily access local networks and industrial clusters, it can obtain significant benefits in promoting productivity, innovation, relevant resources and information (Luo, 2001a). Provinces in Mainland China were categorized into coastal and inland regions to evaluate if location had an influence on HRM practices.

\subsection{Data Collection}

The target organizations for this survey were Japanese companies located in China (JCC), (both Mainland China and Hong Kong) regardless of type, size, ownership or industry, to ensure an adequate number of responses that could generate meaningful results. The questionnaires were addressed to the CEO, HR manager or a person of similar caliber. These respondents were presumed in their official capacity, to be able to represent employers' perspectives.

Three Japanese organizations located in either Mainland China or Hong Kong were contacted to assist with data collection. They were a business consultancy, a recruitment agency, and a Japanese business club (See Table $2^{2}$ ). They agreed to assist with the impartial distribution questionnaires to their clients or members. They sent an introductory letter stating the purpose of the research along with the questionnaire to respondents by email. Respondents were assured that data collected would be confidential and would only be used for academic purposes. A report was offered to the respondents on completion of the survey, for their reference.

Table 2. Profiles of Japanese organizations which supported the survey

\begin{tabular}{|l|l|l|l|}
\hline Organization: & Org1 & Org2 & Org3 \\
\hline Location & Hong Kong & Guangdong & Shanghai \\
\hline Establishment: & 1993 in Hong Kong & 1997 in Japan & 1982 in Shanghai \\
\hline $\begin{array}{l}\text { Busness } \\
\text { Nature: }\end{array}$ & $\begin{array}{l}\text { Labour Law Consulting } \\
\text { HR Development and training } \\
\text { HR System Consulting } \\
\text { Recruiting Process Consulting }\end{array}$ & $\begin{array}{l}\text { Membership service: Advisory service of } \\
\text { company set up, recruitment, } \\
\text { related system establishment. } \\
\text { Indiviudal Project: Tailored made service, } \\
\text { like M\&A, liquidation, re-structure. }\end{array}$ & $\begin{array}{l}\text { Research and related information } \\
\text { collection of trade, investment, finance, } \\
\text { logistic, other economical activities. } \\
\text { Promotion of communication between } \\
\text { Japanese companies located in Shanghai. } \\
\text { Regular arrangement of various seminars } \\
\text { and conference. }\end{array}$ \\
\hline $\begin{array}{l}\text { Email sent } \\
\text { Invalid replies } \\
\begin{array}{l}\text { Valid replies } \\
\text { Successful } \\
\text { response rate: }\end{array}\end{array}$ & 2 & 400 & 3,000 \\
\hline
\end{tabular}

A total of 3,730 emails were sent and 180 valid responses ${ }^{3}$ were selected for analysis after excluding five that did not meet the inclusion criteria specified for this study. Data were analyzed from 180 valid responses from JCCs in the manufacturing and the service sector. Recommendations were then made to improve global HRM practices of Japanese MNCs doing business in China.

The response rates varied by region; this was, $40.8 \%$ in Hong Kong, $12.8 \%$ in Guangdong, and $0.2 \%$ in Shanghai (See Table 2). Table 3 shows the distribution of respondents by industry and location.

\footnotetext{
${ }^{2}$ Table 2 and table 3 are summarized by the author based on the sampling information and demographic data of survey, unless further indicated.

${ }^{3}$ A total of 180 valid replies include 49 by Org 1 (Hong Kong), 51 by Org 2 (Guangdong), 7 by Org 3 (Shanghai) and 73 by the self-contact method.
} 
Table 3. Distribution of samples by industry and location

\begin{tabular}{|c|c|c|c|c|c|c|c|c|c|}
\hline Manufacturing & Bejing & Guangdong & Shanghai & Tianjin & Liaoning & \begin{tabular}{|l|}
$\mathrm{HuNam} /$ \\
Ke Nam
\end{tabular} & $\begin{array}{l}\text { Sichuan/ } \\
\text { Zhongaing }\end{array}$ & Hong Kong & Total: \\
\hline Automobiles & & 3 & 2 & & 1 & 3 & 1 & 1 & 11 \\
\hline Chemical, oil & 1 & 2 & 4 & & & & & 5 & 12 \\
\hline Conveyance machine & & 1 & 1 & & & & & 1 & 3 \\
\hline Electric, machine & 1 & 27 & 7 & 1 & 1 & 1 & & 9 & 47 \\
\hline Steel, metal products & & 7 & 1 & & & 1 & & & 9 \\
\hline Sales - mfg & 1 & 3 & 2 & & & & & 4 & 10 \\
\hline Food and beverage & 1 & & & & & & & 2 & 3 \\
\hline Others-mfg & & 4 & 2 & & & & & 7 & 13 \\
\hline Subtotal: & 4 & 47 & 19 & 1 & 2 & 5 & 1 & 29 & 108 \\
\hline Service & & & & & & & & & \\
\hline Education & & & 2 & & & & & & 2 \\
\hline Finance & & & 1 & & & 1 & & 4 & 6 \\
\hline Information related & 2 & & 4 & & & & & 1 & 7 \\
\hline Insurance & & & & & & & & 2 & 2 \\
\hline Logistic & & & 3 & & & & 1 & 6 & 10 \\
\hline Medical health care & 1 & & & & & & & & 1 \\
\hline Service & 1 & & 4 & & & & & 3 & 8 \\
\hline Trading & 2 & 1 & 4 & & & & & 15 & 22 \\
\hline Other sales & 1 & & 6 & & & & & 7 & 14 \\
\hline Subtotal: & 7 & 1 & 24 & 0 & 0 & 1 & 1 & 38 & 72 \\
\hline Total: & 11 & 48 & 43 & 1 & 2 & 6 & 2 & 67 & 180 \\
\hline
\end{tabular}

For analysis purpose, selected factors which had most responses were used to show the related comparison (See Table 4).

Table 4. Selected explanatory variables for analysis

\begin{tabular}{|l|l|l|}
\hline \multirow{3}{*}{ (1) Industry attributes } & Automobiles & Trading \\
\cline { 2 - 3 } & Chemical & Logistic \\
\cline { 2 - 3 } & Electronic machine & Service \\
\hline (2) Age of JCC & $11^{\sim} 20$ Years \\
\hline (3) Company size of JCC & 100 employees or below \\
\hline (4) Locational factor & Shanghai & Guangdong \\
\hline
\end{tabular}

\section{Findings and Discussions}

The objective of this study was to clarify the differences between HRM practices of JCCs in the manufacturing and the service sector. Taking into consideration that potential readers may include business practitioners, descriptive quantitative analysis with both numerical tables and graphs were presented for ease of comprehension.

\subsection{Country of Origin of Top Management - CEO}

Similar to published literature, respondents indicated that majority of CEOs of JCCs were Japanese. Less than one quarter of respondents stated that the CEOs of their companies were locals.

There is a difference between various industrial sectors and their regional locations. In the service sector in Mainland China, $21 \%$ of companies adopted locals as top management staff. This may be attributed to the need to understand customers' needs in the service sector, in order to approach the market and customers closely.

In mainland China, (25\%) one-fourth of all companies located in the inland region had a local CEO compared to $11 \%$ for companies located at the coastal region. Japanese CEOs may find it inconvenient to work in inland China and JCCs therefore opt to employ more locals as top management staff.

Further comparison illustrating two provinces of Mainland China shows that more companies located in Shanghai adopt locals, compared with the Guangdong area and Hong Kong (Figure 3). 


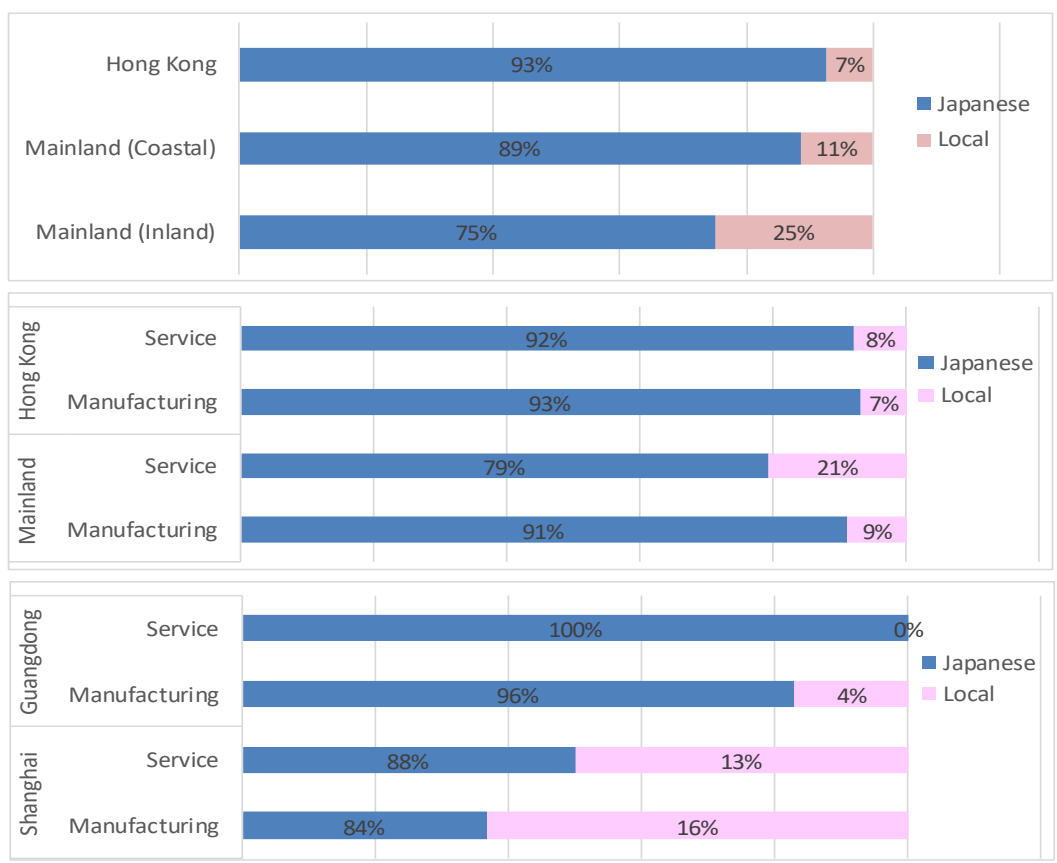

Figure 3: Country of origin of JCCs' CEO

(Manufacturing sector vs Service sector between Mainland China and Hong Kong, and specified locations)

Figure 3. Country of origin of JCCs' CEO

Figure 4 shows that there are no differences in composition of CEOs between companies of different sizes or ages. In general, the findings indicate that the majority of JCCs' CEOs are Japanese, hence supporting Hypothesis 1.

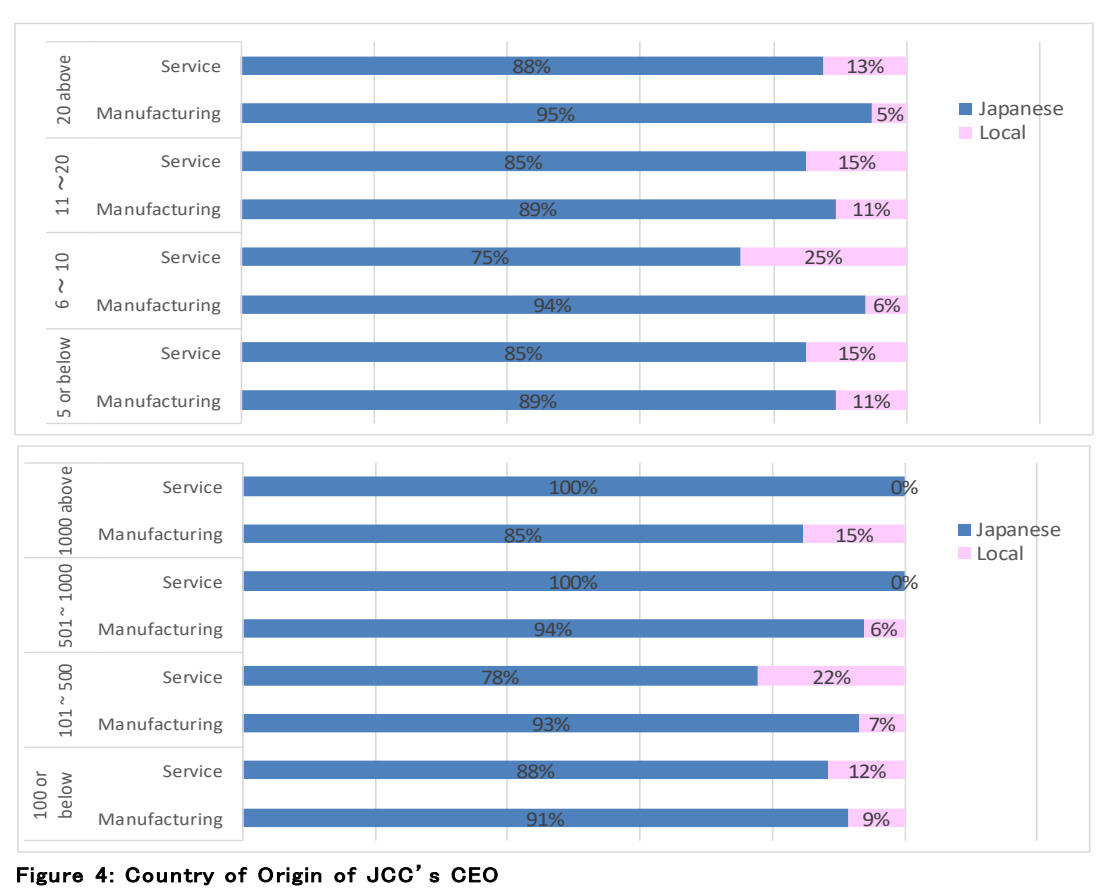

(Manufacturing sector $V_{s}$ Service Sector between various business age, and size of companies)

Figure 4. Country of Origin of JCC's CEO

\subsection{Ranking of Importance of HRM Practices}

\subsubsection{Overall Ranking}

Figure 5a shows the ranking result of five key HRM practices, and Figure 5b demonstrates the result of the manufacturing and the service sector in Mainland China and Hong Kong after the summation of points is calculated respectively. According to the result of ranking amongst five key HRM practices, most respondents ranked "performance appraisal" as most important and the second important. 


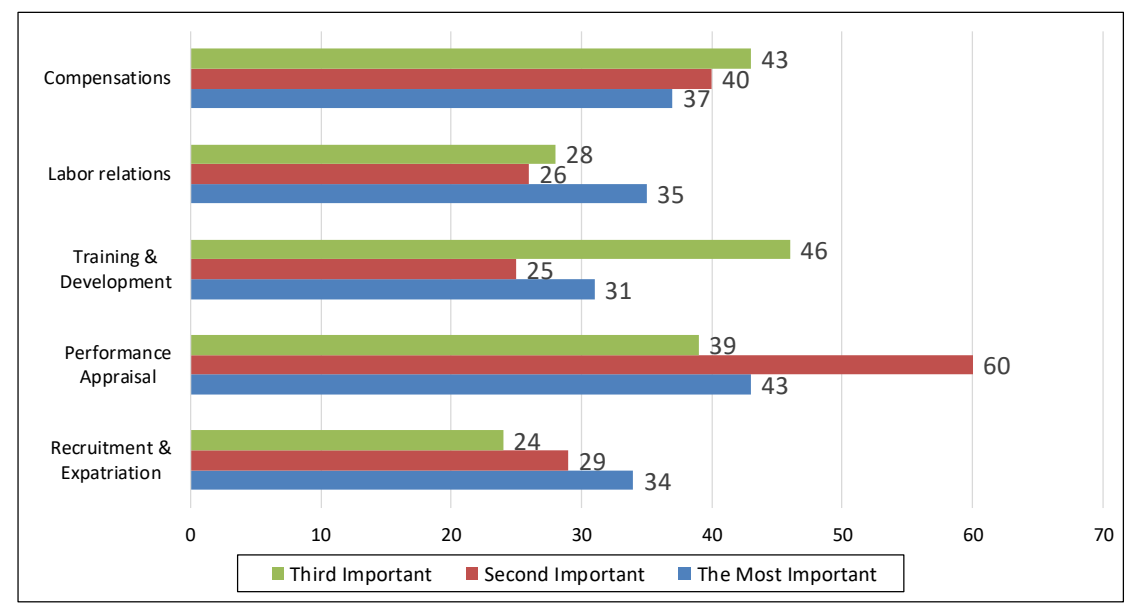

Figure 5a. Ranking of importance of HRM Practice

\subsubsection{By Industry and Region}

Since the number of samples of each sector is different, we assessed the five HRM practices in each region and each sector separately with $100 \%$ as a total of the five HRM practices in each sector in each region (Table 5). "Performance appraisal" was rated as the most important in most sectors, except for the service sector in Mainland China where "compensation and rewards" was rated as the most important HRM practice. However, the difference in ranking between the most important HRM practices i.e. performance appraisal and compensation and rewards was very small (Figure 5b).

Table 5. Ranking of importance of HRM Practice (After summation of grade-point's calculation)

(Manufacturing sector vs Service sector between Mainland China and Hong Kong)
\begin{tabular}{|l|r|r|r|r|}
\hline & \multicolumn{2}{|c|}{ Mainland China } & \multicolumn{2}{c|}{ Hong Kong } \\
\hline HRM Practice & Manufacturing & \multicolumn{1}{c|}{ Service } & Manufacturing & \multicolumn{1}{c|}{ Service } \\
\hline Compensation & $20.5 \%$ & $24.8 \%$ & $22.4 \%$ & $20.6 \%$ \\
\hline Labor Relations & $20.1 \%$ & $11.9 \%$ & $17.2 \%$ & $15.8 \%$ \\
\hline Training \& Development & $15.4 \%$ & $17.6 \%$ & $19.0 \%$ & $20.6 \%$ \\
\hline Performance Appraisal & $27.8 \%$ & $23.3 \%$ & $29.9 \%$ & $25.0 \%$ \\
\hline Recruitment \& Expatration & $16.2 \%$ & $22.4 \%$ & $11.5 \%$ & $18.0 \%$ \\
\hline Total: & $100 \%$ & $100 \%$ & $100 \%$ & $100 \%$ \\
\hline
\end{tabular}

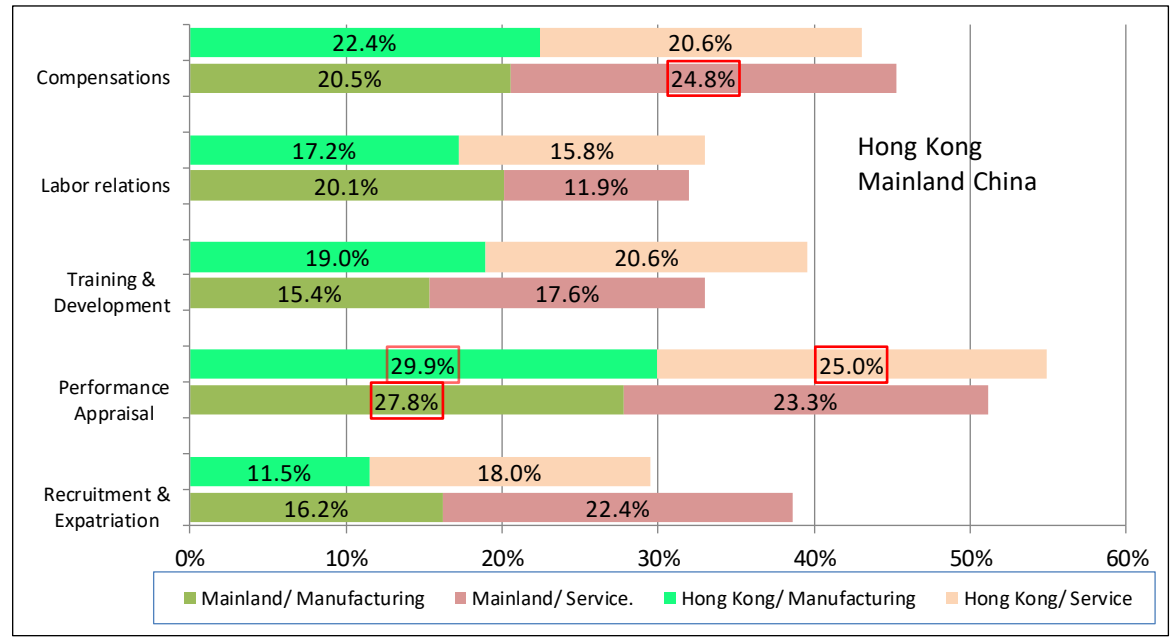

Figure 5b: Ranking of importance of HRM Practice (After summation of grade-point's calculation)

(Manufacturing sector vs Service sector between Mainland China and Hong Kong)

Figure 5b. Ranking of importance of HRM Practice (After summation of grade-point's calculation)

\subsubsection{By Company Age, Size, and Specified Location}

The result of the five HRM practices by company's age, size, and specified location is demonstrated to show the frequency of each rating (Table 6). 
Table 6 . The result of the five HRM practices by company age, size and specified location

\begin{tabular}{|c|c|c|c|c|c|}
\hline & $\begin{array}{l}\text { Recruitment \& } \\
\text { Expatriation }\end{array}$ & $\begin{array}{l}\text { Performance } \\
\text { Appraisal }\end{array}$ & $\begin{array}{l}\text { Training \& } \\
\text { Development }\end{array}$ & Labor Relations & Compensation \\
\hline \multicolumn{6}{|l|}{ Age of JCCs } \\
\hline 5 or below & & & & & \\
\hline The Most Important & 2 & 4 & 2 & 4 & 3 \\
\hline Second Important & 3 & 5 & 2 & 2 & 3 \\
\hline Third Important & 3 & 3 & 6 & 0 & 3 \\
\hline \multicolumn{6}{|l|}{$6 \sim 10$} \\
\hline The Most Important & 8 & 5 & 4 & 9 & 2 \\
\hline Second Important & 6 & 10 & 4 & 2 & 6 \\
\hline Third Important & 3 & 5 & 8 & 4 & 8 \\
\hline \multicolumn{6}{|l|}{$11 \sim 20$} \\
\hline The Most Important & 14 & 14 & 10 & 13 & 16 \\
\hline Second Important & 11 & 24 & 7 & 11 & 14 \\
\hline Third Important & 11 & 15 & 15 & 7 & 19 \\
\hline \multicolumn{6}{|l|}{$21 \sim 30$} \\
\hline The Most Important & 8 & 14 & 12 & 5 & 6 \\
\hline Second Important & 7 & 13 & 6 & 7 & 12 \\
\hline Third Important & 6 & 8 & 10 & 14 & 7 \\
\hline \multicolumn{6}{|l|}{31 above } \\
\hline The Most Important & 2 & 6 & 3 & 4 & 10 \\
\hline Second Important & 2 & 8 & 6 & 4 & 5 \\
\hline Third Important & 1 & 8 & 7 & 3 & \\
\hline \multicolumn{6}{|c|}{ Company size of JCCs } \\
\hline 100 or below & & & & & \\
\hline The Most Important & 16 & 19 & 17 & 18 & 17 \\
\hline Second Important & 8 & 30 & 14 & 14 & 21 \\
\hline Third Important & 16 & 21 & 18 & 11 & 21 \\
\hline $101 \sim 500$ & & & & & \\
\hline The Most Important & 14 & 17 & 6 & 12 & 13 \\
\hline Second Important & 14 & 20 & 11 & 5 & 12 \\
\hline Third Important & 7 & 12 & 19 & 10 & 14 \\
\hline $501 \sim 1000$ & & & & & \\
\hline The Most Important & 2 & 4 & 4 & 3 & 4 \\
\hline Second Important & 4 & 7 & 0 & 5 & 1 \\
\hline Third Important & 1 & 1 & 5 & 4 & 6 \\
\hline 1000 above & & & & & \\
\hline The Most Important & 2 & 3 & 4 & 2 & 3 \\
\hline Second Important & 3 & 3 & 0 & 2 & 6 \\
\hline Third Important & 0 & 5 & 4 & 3 & \\
\hline Location of JC & & & & & \\
\hline Shanghai & & & & & \\
\hline The Most Important & 12 & 7 & 6 & 7 & 11 \\
\hline Second Important & 6 & 14 & 3 & 7 & 13 \\
\hline Third Important & 10 & 11 & 9 & 4 & 9 \\
\hline Guangdong & & & & & \\
\hline The Most Important & 6 & 13 & 11 & 11 & 7 \\
\hline Second Important & 9 & 16 & 5 & 7 & 11 \\
\hline Third Important & 3 & 12 & 11 & 10 & 12 \\
\hline Liaoning & & & & & \\
\hline The Most Important & 1 & 0 & 0 & 1 & 0 \\
\hline Second Important & 0 & 0 & 1 & 0 & 1 \\
\hline Third Important & 0 & 0 & 1 & 1 & 0 \\
\hline Bejing & & & & & \\
\hline The Most Important & 1 & 3 & 2 & 2 & 3 \\
\hline Second Important & 4 & 3 & 2 & 1 & 1 \\
\hline Third Important & 1 & 2 & 4 & 1 & 3 \\
\hline Hong Kong & & & & & \\
\hline The Most Important & 13 & 15 & 12 & 12 & 15 \\
\hline Second Important & 7 & 25 & 13 & 10 & 12 \\
\hline Third Important & 8 & 14 & 18 & 10 & 17 \\
\hline Chongqing & & & & & \\
\hline The Most Important & 1 & 0 & 0 & 0 & 0 \\
\hline Second Important & 0 & 1 & 0 & 0 & 0 \\
\hline Third Important & 0 & 0 & 1 & 0 & \\
\hline Sichuan & & & & & \\
\hline The Most Important & 0 & 1 & 0 & 0 & 0 \\
\hline Second Important & 0 & 0 & 0 & 1 & 0 \\
\hline Third Important & 1 & 0 & 0 & 0 & \\
\hline KeNam & & & & & \\
\hline The Most Important & 0 & 0 & 0 & 1 & 1 \\
\hline Second Important & 2 & 0 & 0 & 0 & 0 \\
\hline Third Important & 0 & 0 & 1 & 0 & 1 \\
\hline HuNan & & & & & \\
\hline The Most Important & 0 & 3 & 0 & 1 & 0 \\
\hline Second Important & 1 & 1 & 1 & 0 & 1 \\
\hline Third Important & 1 & 0 & 0 & 2 & \\
\hline Tianjin & & & & & \\
\hline The Most Important & 0 & 1 & 0 & 0 & 0 \\
\hline Second Important & 0 & 0 & 0 & 0 & $\begin{array}{l}1 \\
0\end{array}$ \\
\hline Third Important & 0 & 0 & 1 & 0 & 0 \\
\hline
\end{tabular}


Figure 6 shows that companies in the service sector with 11 to 20 years of business experience, or with 100 employees or fewer rated "compensation and rewards" as the most important HRM practice. Notably, companies in the service sector located in Shanghai and Guangdong put the highest rating on "compensation and rewards" and "training and education", respectively.

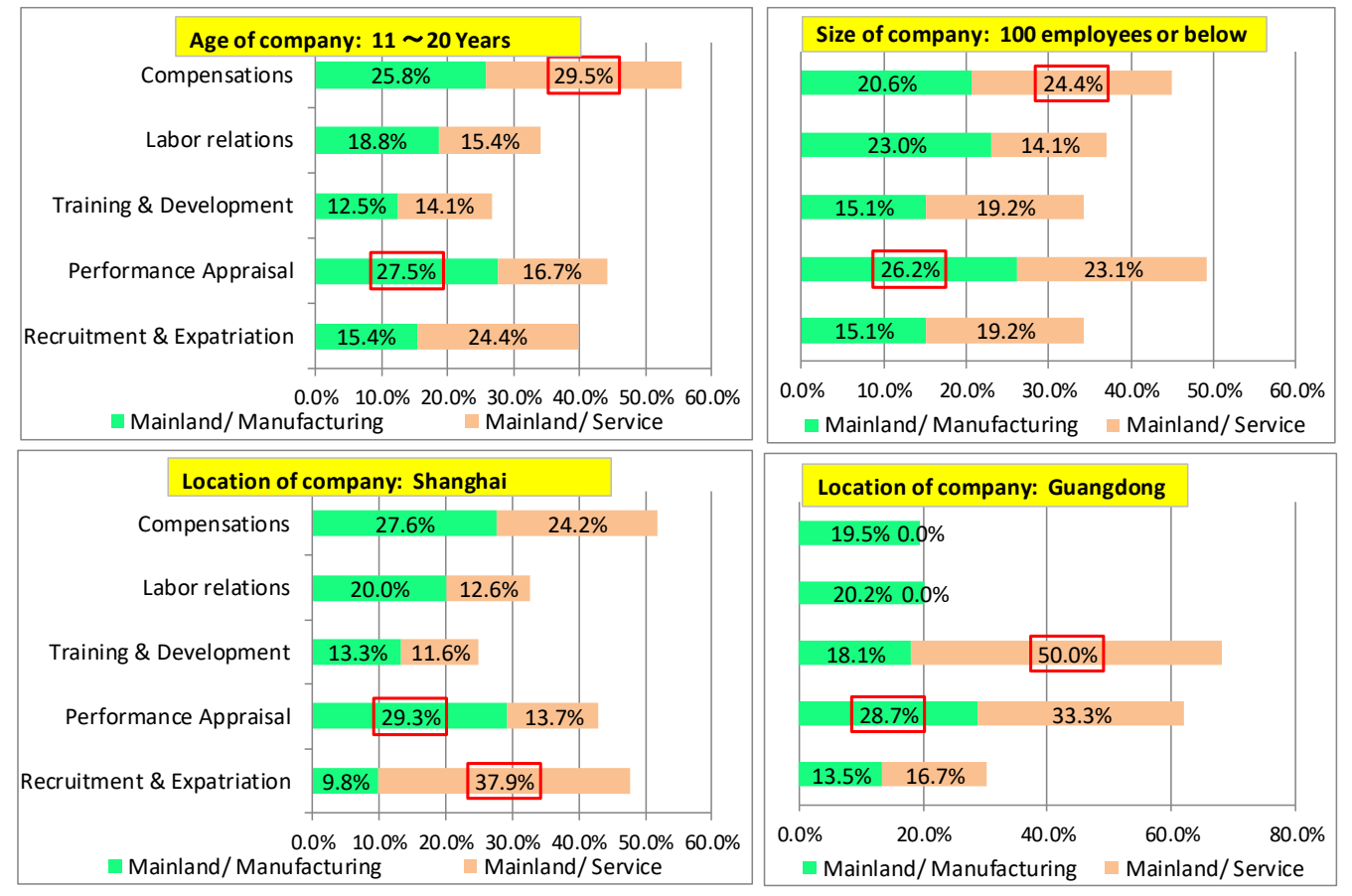

Figure 6: Ranking of importance of HRM Practice

(Manufacturing sector vs Service sector between various location, size, business age, and size of companies)

Figure 6. Ranking of importance of HRM Practice

5.2.4 By Industry

In similar way, the result of the five HRM practices by industry is demonstrated to show the frequency of each rating (Table 7). 
Table 7. The result of the five HRM practices by company's industry

\begin{tabular}{|c|c|c|c|c|c|}
\hline & $\begin{array}{l}\text { Recruitment \& } \\
\text { Expatriation }\end{array}$ & $\begin{array}{c}\text { Performance } \\
\text { Appraisal }\end{array}$ & $\begin{array}{c}\text { Training \& } \\
\text { Development }\end{array}$ & $\begin{array}{c}\text { Labor } \\
\text { Relations }\end{array}$ & Compensation \\
\hline \multicolumn{6}{|c|}{ Manufacturing Industry } \\
\hline \multicolumn{6}{|c|}{ Chemical, oil } \\
\hline The Most Important & 0 & 4 & 2 & 2 & 4 \\
\hline Second Important & 1 & 4 & 3 & 2 & 2 \\
\hline Third Important & 1 & 3 & 4 & 1 & 3 \\
\hline \multicolumn{6}{|l|}{ Steel, metal products } \\
\hline The Most Important & 0 & 1 & 1 & 6 & 1 \\
\hline Second Important & 1 & 5 & 0 & 0 & 3 \\
\hline Third Important & 1 & 2 & 2 & 2 & 2 \\
\hline \multicolumn{6}{|l|}{ Electric, machine } \\
\hline The Most Important & 10 & 15 & 6 & 8 & 8 \\
\hline Second Important & 12 & 12 & 5 & 6 & 12 \\
\hline Third Important & 3 & 9 & 13 & 10 & 12 \\
\hline \multicolumn{6}{|l|}{ Conveyance machine } \\
\hline The Most Important & 1 & 1 & 0 & 0 & 1 \\
\hline Second Important & 0 & 0 & 0 & 2 & 1 \\
\hline Third Important & 1 & 2 & 0 & 0 & 0 \\
\hline \multicolumn{6}{|l|}{ Sales - mfg } \\
\hline The Most Important & 0 & 2 & 4 & 2 & 2 \\
\hline Second Important & 1 & 6 & 1 & 0 & 2 \\
\hline Third Important & 1 & 1 & 1 & 2 & 5 \\
\hline \multicolumn{6}{|l|}{ Automobiles } \\
\hline The Most Important & 3 & 4 & 0 & 3 & 1 \\
\hline Second Important & 2 & 2 & 3 & 2 & 2 \\
\hline Third Important & 2 & 2 & 4 & 1 & 2 \\
\hline \multicolumn{6}{|l|}{ Food and beverage } \\
\hline The Most Important & 2 & 1 & 0 & 0 & 0 \\
\hline Second Important & 1 & 0 & 2 & 0 & 0 \\
\hline Third Important & 0 & 0 & 0 & 2 & 1 \\
\hline \multicolumn{6}{|l|}{ Others-mfg } \\
\hline The Most Important & 0 & 3 & 2 & 4 & 1 \\
\hline Second Important & 0 & 4 & 0 & 2 & 4 \\
\hline Third Important & 1 & 1 & 5 & 0 & 3 \\
\hline \multicolumn{6}{|l|}{ Service Industry } \\
\hline Trading & & & & & \\
\hline The Most Important & 5 & 3 & 5 & 3 & 6 \\
\hline Second Important & 4 & 8 & 3 & 5 & 2 \\
\hline Third Important & 4 & 7 & 1 & 3 & 7 \\
\hline \multicolumn{6}{|l|}{ Service } \\
\hline The Most Important & 1 & 1 & 4 & 0 & 2 \\
\hline Second Important & 1 & 3 & 1 & 1 & 2 \\
\hline Third Important & 1 & 2 & 1 & 3 & 1 \\
\hline Finance & & & & & \\
\hline The Most Important & 1 & 1 & 3 & 1 & 0 \\
\hline Second Important & 1 & 3 & 0 & 2 & 0 \\
\hline Third Important & 3 & 1 & 0 & 1 & 1 \\
\hline Logistic & & & & & \\
\hline The Most Important & 4 & 1 & 0 & 2 & 3 \\
\hline Second Important & 1 & 2 & 2 & 3 & 2 \\
\hline Third Important & 3 & 1 & 5 & 1 & 0 \\
\hline Insurance & & & & & \\
\hline The Most Important & 0 & 1 & 0 & 0 & 1 \\
\hline Second Important & 0 & 0 & 1 & 0 & 1 \\
\hline Third Important & 0 & 1 & 1 & 0 & 0 \\
\hline Information related & & & & & \\
\hline The Most Important & 2 & 3 & 0 & 1 & 1 \\
\hline Second Important & 2 & 2 & 1 & 0 & 2 \\
\hline Third Important & 1 & 1 & 2 & 0 & 3 \\
\hline Medical health care & & & & & \\
\hline The Most Important & 0 & 1 & 0 & 0 & 0 \\
\hline Second Important & 0 & 0 & 0 & 0 & 1 \\
\hline Third Important & 0 & 0 & 1 & 0 & 0 \\
\hline Education & & & & & \\
\hline The Most Important & 1 & 0 & 1 & 0 & 0 \\
\hline Second Important & 0 & 2 & 0 & 0 & 0 \\
\hline Third Important & 1 & 0 & 0 & 1 & 0 \\
\hline Other Service & & & & & \\
\hline The Most Important & 4 & 1 & 2 & 3 & 6 \\
\hline Second Important & 2 & 6 & 3 & 1 & 4 \\
\hline Third Important & 2 & 7 & 7 & 1 & 2 \\
\hline
\end{tabular}

Respondents from automobiles, chemical, and electronic machines industries in the manufacturing sector ranked "performance appraisal" as the most important practice, while companies involved in trading and other service 
industries in the service sector gave the highest rating to "compensation and rewards" and "recruitment" respectively (see Figure 7).
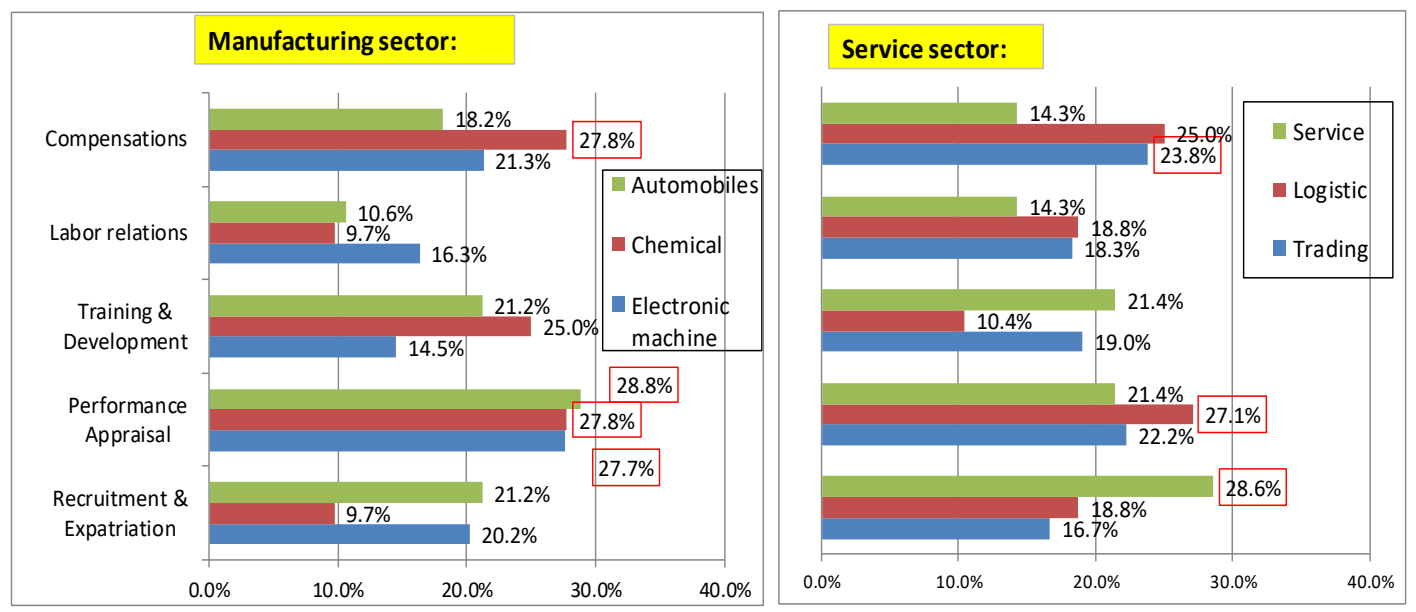

Figure 7: Ranking of importance of HRM Practice

(Manufacturing sector vs Service sector between various industries of companies)

\subsection{Decisions for Expatriation}

Figure 7. Ranking of importance of HRM Practice

Several factors were categorized into two groups: the Japan headquarters and the overseas subsidiaries perspectives. Respondents were asked to indicate the rankings on the Japan headquarters perspective (See table 8).

Table 8. Ranking of important factors of expatration's consideration

\begin{tabular}{|l|r|r|r|r|}
\hline & \multicolumn{2}{|c|}{ Mainland China } & \multicolumn{2}{c|}{ Hong Kong } \\
\cline { 2 - 5 } & Manufacturing & \multicolumn{1}{|c|}{ Service } & Manufacturing & \multicolumn{1}{c|}{ Service } \\
\hline Japan Headquarters' perspective & & & & $11.7 \%$ \\
\hline Availability of Talents (HQ) & $6.3 \%$ & $11.8 \%$ & $8.6 \%$ & $13.6 \%$ \\
\hline Technical gap & $11.4 \%$ & $10.8 \%$ & $5.0 \%$ \\
\hline Experience of global business & $15.5 \%$ & $17.6 \%$ & $3.7 \%$ & $11.3 \%$ \\
\hline Investment style & $3.9 \%$ & $2.0 \%$ & $1.3 \%$ \\
\hline Performance contribution to HQ & $21.2 \%$ & $13.7 \%$ & $28.2 \%$ & $23.1 \%$ \\
\hline Localizatio promotion & $15.1 \%$ & $16.2 \%$ & $15.3 \%$ & $10.4 \%$ \\
\hline Corporate policy (Integration) & $26.6 \%$ & $27.9 \%$ & $26.4 \%$ & $35.3 \%$ \\
\hline Total: & $100.0 \%$ & $100.0 \%$ & $100.0 \%$ & $100.0 \%$ \\
\hline Overseas Subsidiaries' perspective & & & & $25.6 \%$ \\
\hline Availability of Talents (Local) & $18.7 \%$ & $22.2 \%$ & $0.5 \%$ & $16.4 \%$ \\
\hline Locational advantage & $4.4 \%$ & $2.5 \%$ & $10.4 \%$ & $15.5 \%$ \\
\hline Local operation risk & $23.8 \%$ & $22.2 \%$ & $10.4 \%$ & $13.6 \%$ \\
\hline Size of company & $6.0 \%$ & $5.4 \%$ & $37.2 \%$ & $34.5 \%$ \\
\hline Complexibility of business & $31.9 \%$ & $30.0 \%$ & $15.9 \%$ & $15.5 \%$ \\
\hline Years of business operation & $15.2 \%$ & $17.7 \%$ & $100.0 \%$ & $100.0 \%$ \\
\hline Total: & $100.0 \%$ & $100.0 \%$ & & \\
\hline
\end{tabular}

\subsubsection{Japanese Headquarters Perspectives}

The majority of respondents rated "corporate policy for integration" as the most important factor affecting the decision of assigning expatriates working in overseas subsidiaries (26.6\% in the Mainland manufacturing sector, $27.9 \%$ in the Mainland service sector, and 35.3\% in the Hong Kong service sector), while respondents from the Hong Kong manufacturing sector rated "contribution of overseas subsidiaries to headquarters" as the most important factor. Most respondents felt that the Japan headquarters uses Japanese expatriates to achieve their purpose of integrating overseas operation. Besides the Mainland manufacturing sector, the respondents in the Mainland service sector, and the Hong Kong service sector also rated "contribution of overseas subsidiaries to headquarters" as the second most important 
consideration of expatriation, while the Mainland service sector rated "experience of global business (17.6\%)" as the second most important consideration of expatriation (See figure 8).

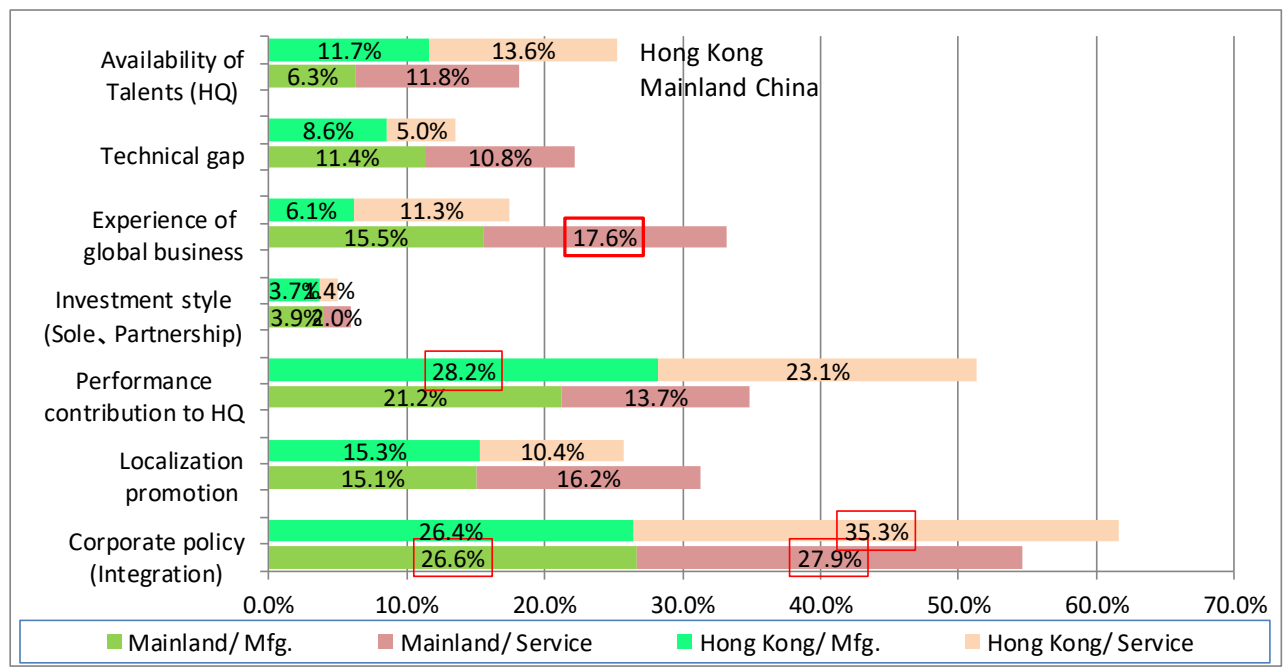

Figure 8: Important factors of Expatriation's considerations (From Headquarters' point of view) (Manufacturing sector vs Service sector between Mainland China and Hong Kong)

Figure 8. Important factors of Expatriation's considerations (Form Headquarters' point of view)

In Figure 9, a similar result was obtained in each selected range of years of business, size, and specified location of JCCs.

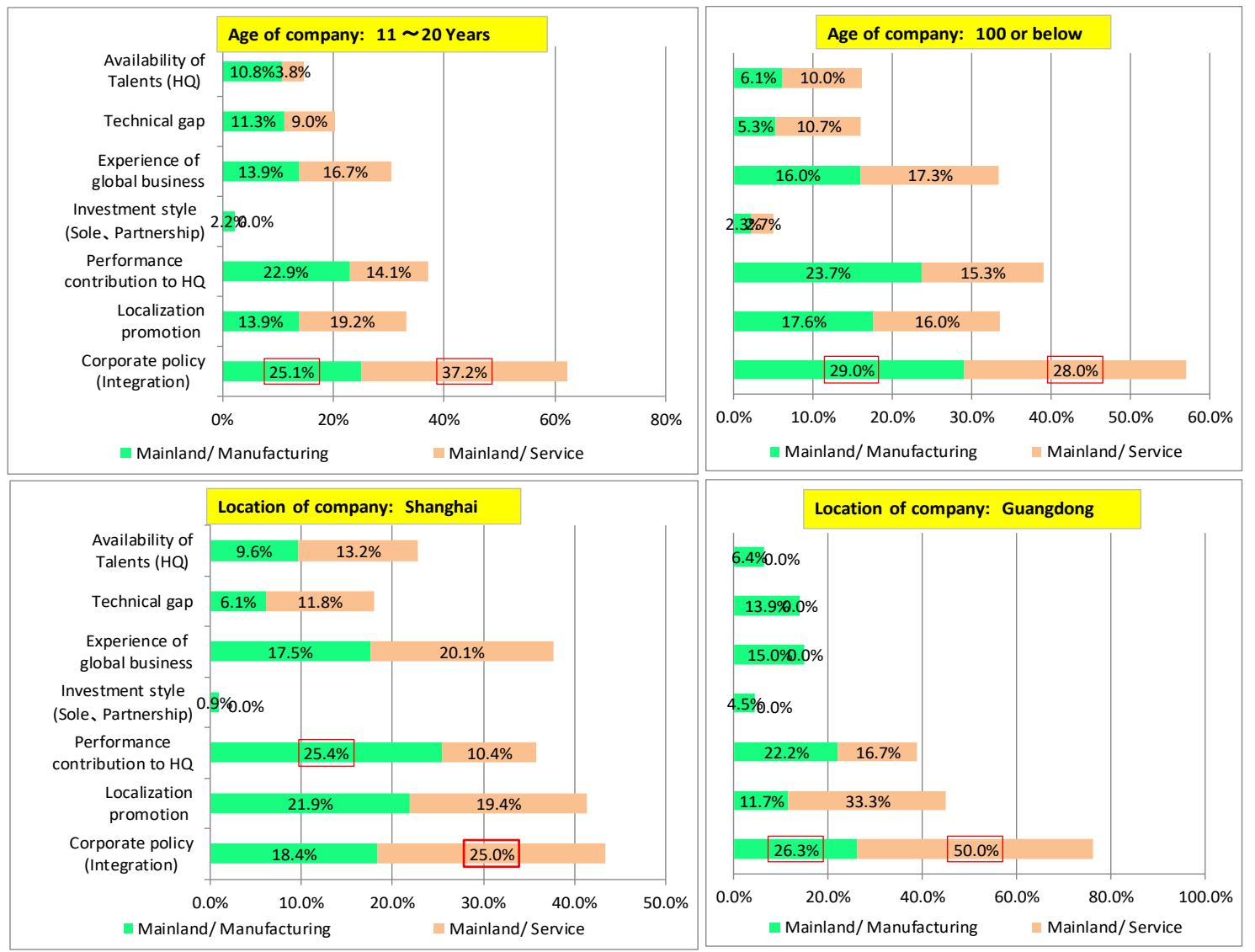

Figure 9: Important factors of Expatriation's considerations (From Headquarters' point of view)

Figure 9: Important factors of Expatriation's considerations (From Headquarters' point of view)
(Manufacturing sector vs Service sector between various location, size, business age, and size of companies)

Figure 9. Important factors of Expatriation's considerations (Form Headquarters' point of view) 


\subsubsection{Overseas Subsidiaries Perspectives}

Figure 10 shows the result of the overseas subsidiaries side. Over one-third of each group of respondents ranked "complexity of business" as the most important factor of consideration in expatriation. This implies that overseas affiliates expect support from headquarters when they encounter difficulties in running the business. Notably, "availability of local talents" and "local operation risks" were rated as the second and third most important factors affecting the expatriation's consideration from the overseas affiliates' point of view.

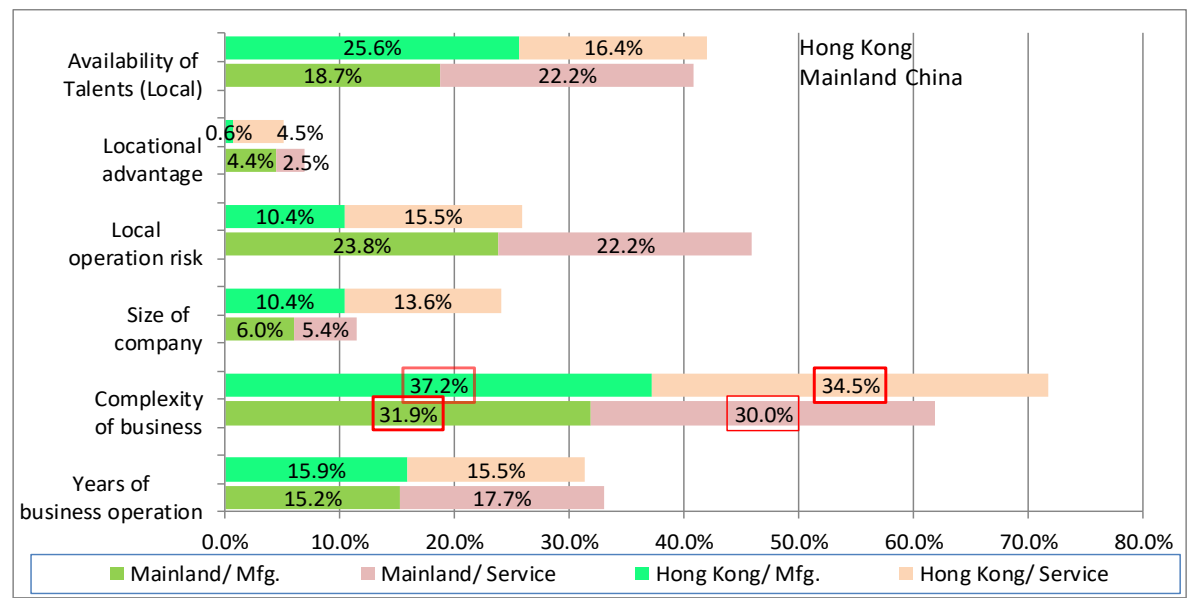

Figure 10: Important factors of Expatriation's considerations (From Subsidaries' point of view)

(Manufacturing sector vs Service sector between various location, size, business age, and size of companies)

Figure 10. Important factors of Expatriation's considerations (From Subsidiaries' point of view)

In Figure 11, almost same result was obtained in each selected range of years of business, size, and specified location of JCCs.

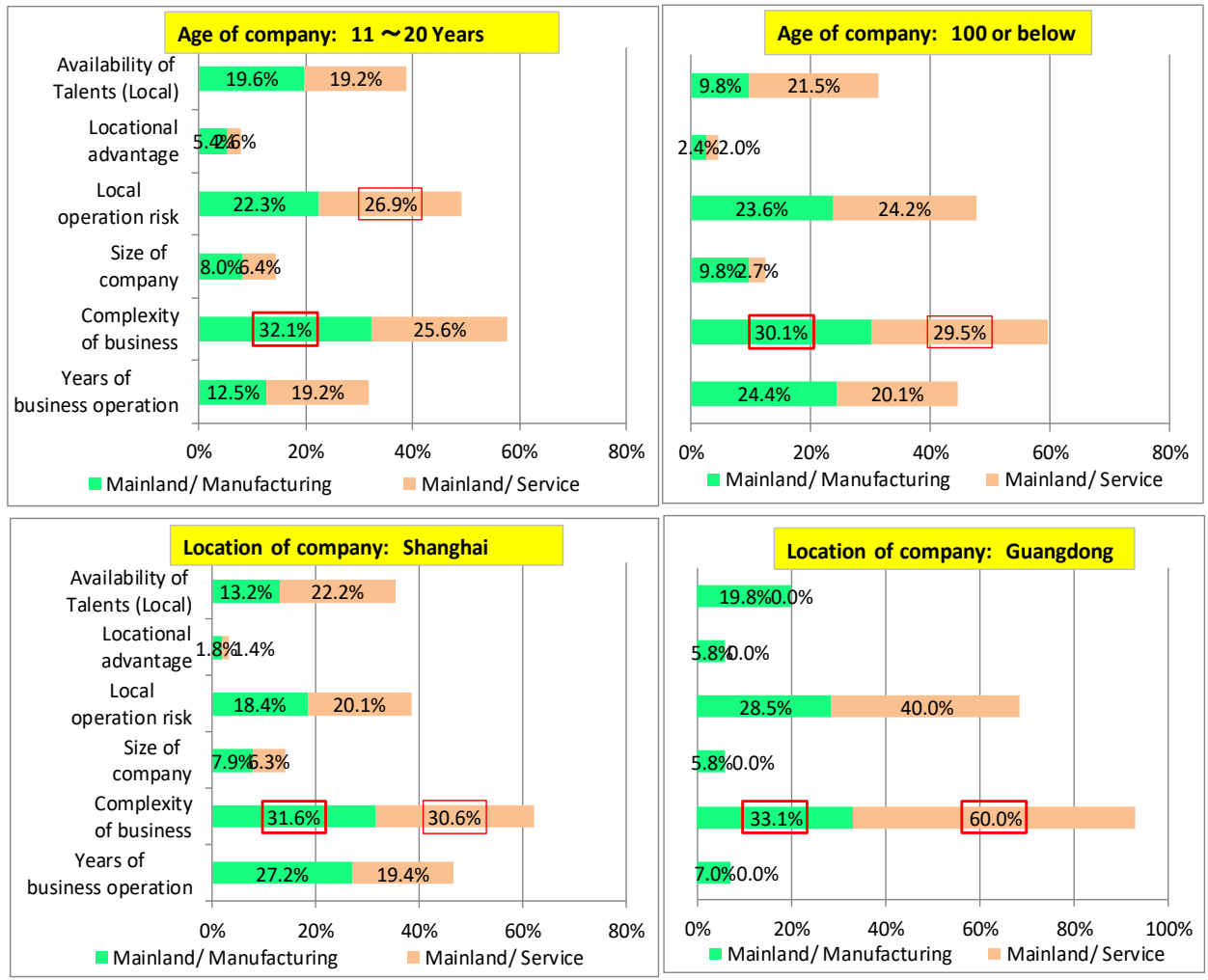

Figure 11: Important factors of Expatriation's considerations (From Subsidaries' point of view)

(Manufacturing sector vs Service sector between various location, size, business age, and size of companies)

Figure 11. Important factors of Expatriation's considerations (From Subsidiaries' point of view) 


\subsubsection{Reasons for Expatriation}

Interestingly, according to the result shown in Figure 12, respondents in the manufacturing and the service sector of both Mainland China and Hong Kong indicate different reason of expatriation. Over $40 \%$ of respondents in the service sector reported "communication enhancement between headquarters and subsidiaries" as the main reason for expatriation, while nearly $40 \%$ of respondents in the manufacturing sector put the highest rating on "improvement of local management”.

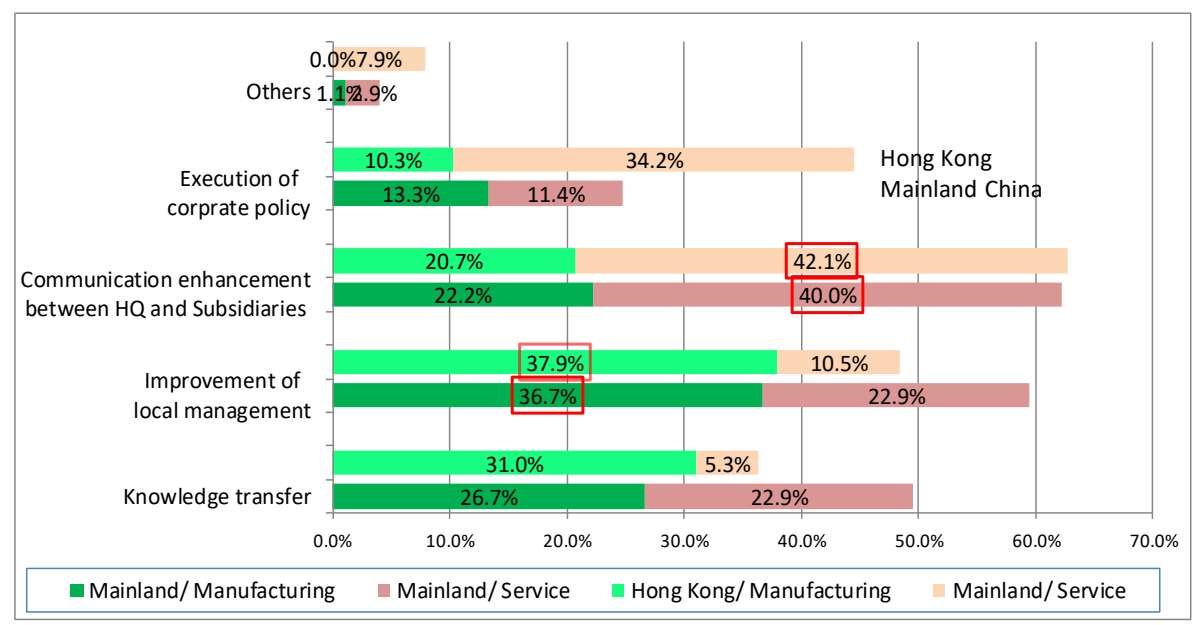

Figure 12. Main Purpose of Expatriation from Japan headquarters' view

During the further review using the other factors, a variety of outcomes are obtained see Figures 13 and 14). JCCs in the age group of 11 to 20 years in the Mainland manufacturing sector, and JCCs with 100 or below employees in both the Mainland manufacturing and service sector rated "communication enhancement between headquarters and subsidiaries" as the main reason for expatriation. JCCs in the age group of 11 to 20 years in the Mainland service sector put the highest rating on "improvement of local management". In addition, Shanghai's JCCs in the manufacturing and the service sector rated "improvement of local management" and "transfer of knowledge" as the main reasons, respectively. Regarding the individual industries in the manufacturing and the service sector, JCCs of each group have different rating about the main reason of expatriation from Japan headquarters.

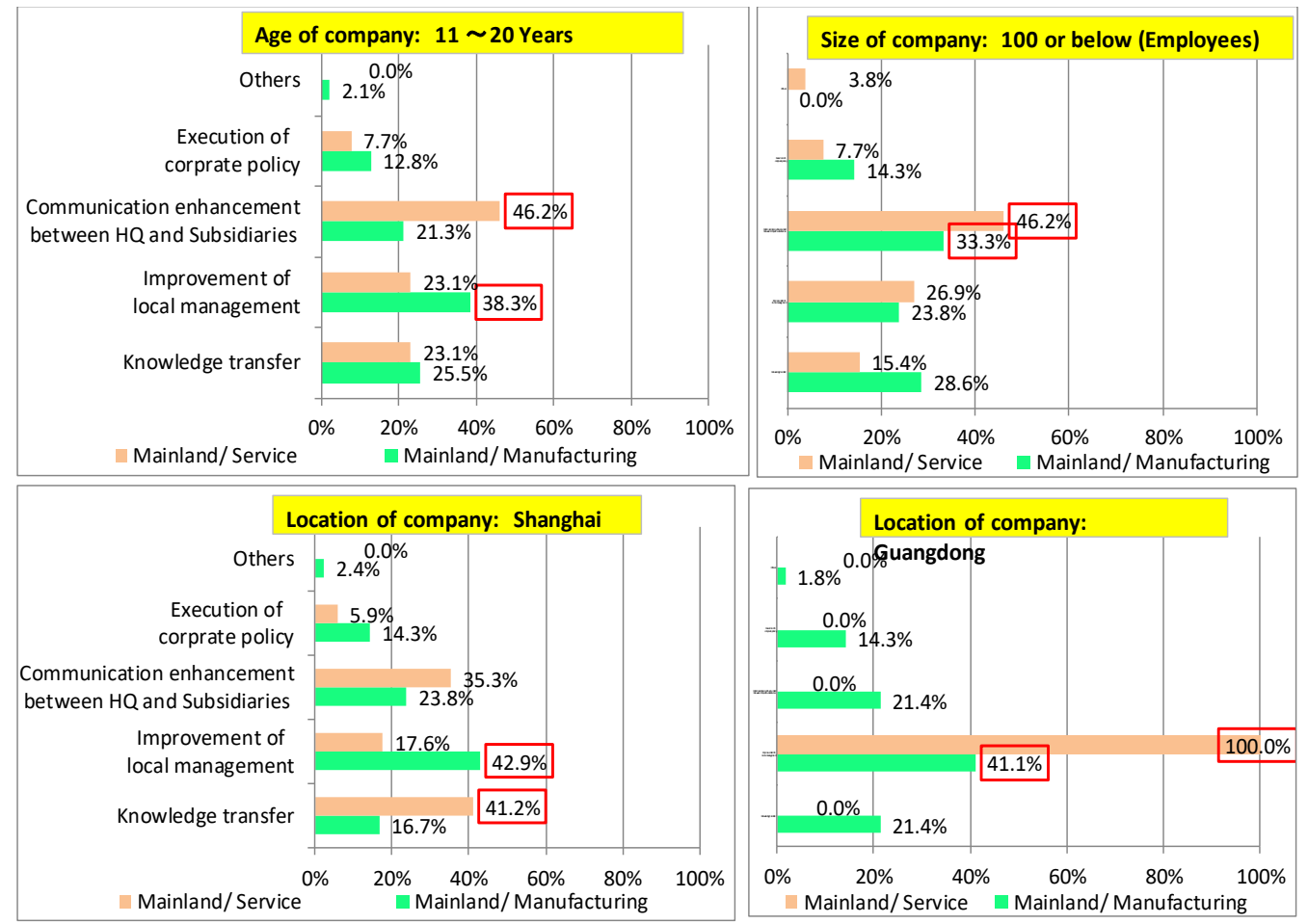

Figure 13. Main Purpose of Expatriation from Japan headquarters' view 


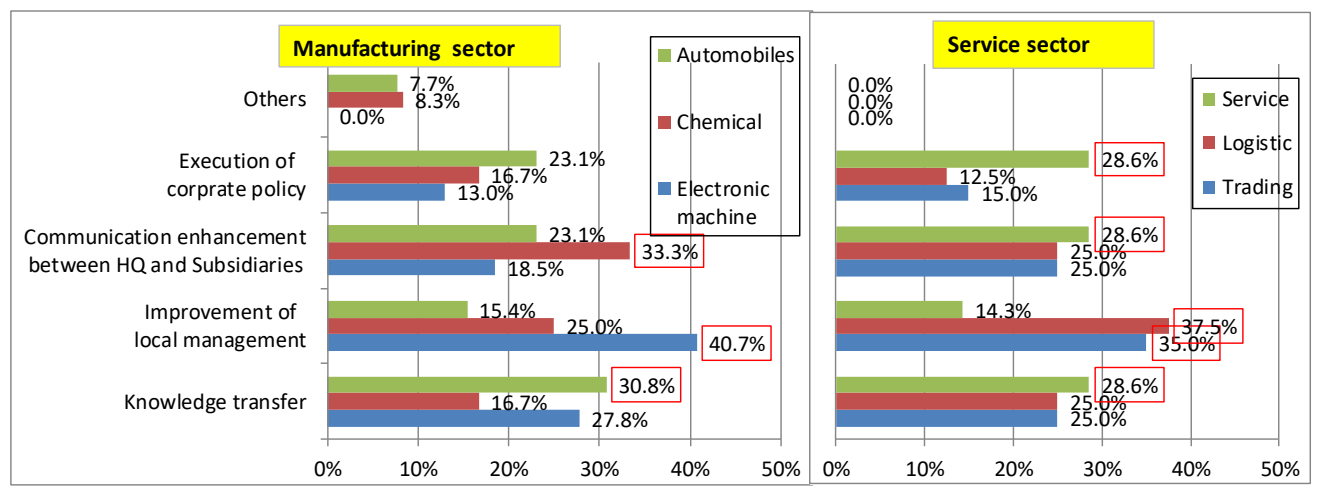

Figure 14: Main Purpose of Expatriation from Japan headquartersview)

(Manufacturing sector vs Service sector between various industries of companies)

Figure 14. Main Purpose of Expatriation from Japan headquarters' view

\subsubsection{Criteria for Expatriation}

According the result shown in Figure 15, "own skills and knowledge of expatriate" got the highest rating among all groups of the manufacturing and the service sector in Mainland China and Hong Kong. Next to it, "handling skills of culture difference" was the second highest chosen requirement of expatriates. When reviewing each independent group, responses did not differ in the manufacturing and the service sector.

When testing Hypothesis 3, there were certain differences in "the main purpose of expatriation" and "the factors affecting the consideration of expatriation from overseas subsidiaries' point of view" between the manufacturing and the service sector, while there were no differences in "the criteria of expatriates' selection" from the headquarters' point of view".

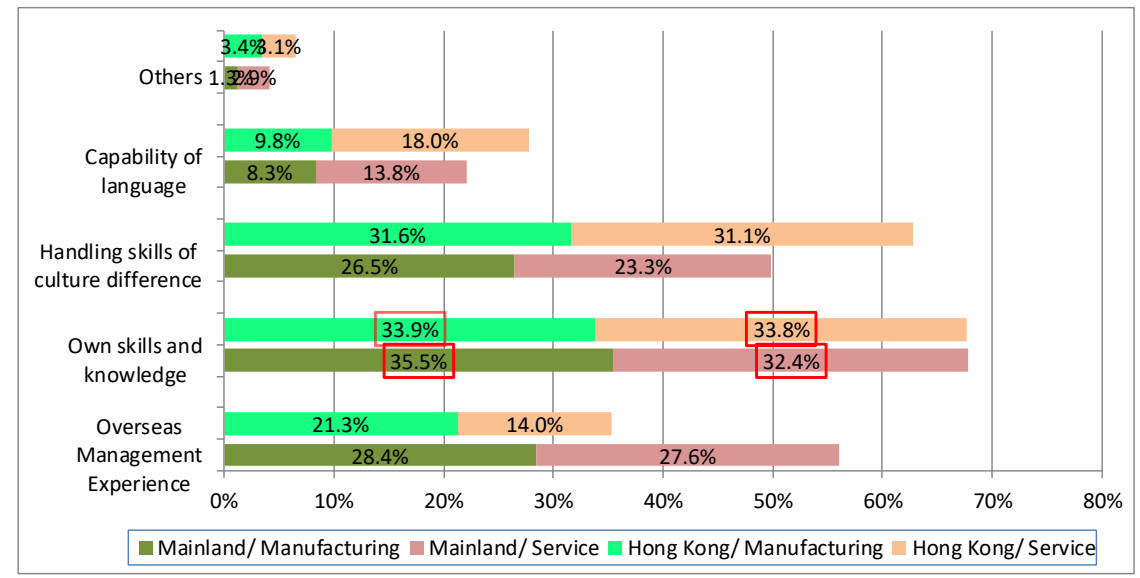

Figure 15: Important criteria of expatriates' selection

(Manufacturing sector vs Service sector between Mainland China and Hong Kong)

Figure 15. Important criteria of expatriates' selection

\section{Discussion of Findings}

Despite the growing importance of HRM as an innovative source of competitive business advantage, limited empirical research has focused on the analysis of differences between the companies in the manufacturing and the service sector. Understanding the differences between manufacturing and service companies from a HR perspective is an essential prerequisite since the business environment in Mainland China is moving towards a more service oriented field. This study compared the differences in HRM practices between the manufacturing and the service sector of JCCs in both Mainland China and Hong Kong. In general, there were similarities between two sectors; some variations however, were observed by industry attributes, locations, ages, and sizes of companies.

Firstly, the majority of CEOs or top managers of JCCs were Japanese, regardless of company or sector characteristics, similar to published literature. Although research has shown a higher ratio of CEOs selected from the local population in other countries, localization in managing overseas operations may not necessarily be better than integrated control by headquarters. The assignment of a CEO to an overseas subsidiary is a crucial decision for each MNC. For example, a higher percentage 'locals' in CEO positions in the service sector could be interpreted as the need for the senior 
management in overseas subsidiaries to be as close as possible to the domestic market in order to effectively manage local employees. Hong Kong's JCCs have an extremely high percentage of Japanese CEOs; this implies that they are still unable to fully recognize the need for local leader, even in the presence of a mature and stable business environment in the Hong Kong service industry.

Secondly, performance appraisal was ranked the most important among all HRM practices. Compensation was ranked second most important among respondents from Shanghai and from service companies in Mainland China. The result approximates those of previous studies highlighted in the literature review. Despite the fact that all HRM practices are inter-related, the outcomes of performance appraisals directly influence other HR fields, especially the determination of employee remuneration (see Figure 16).

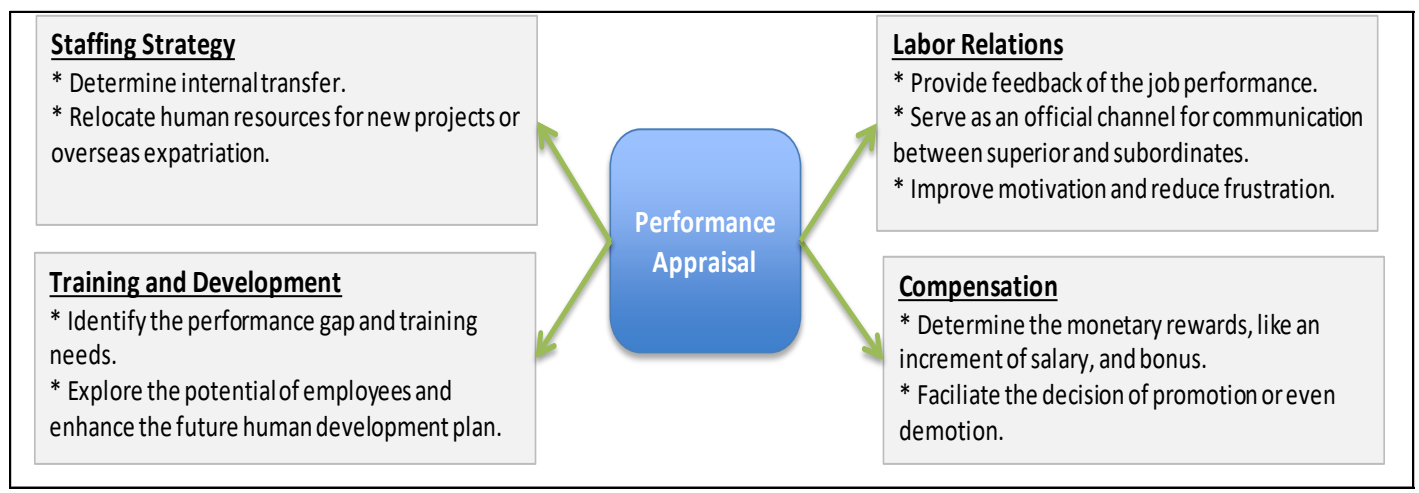

Figure 16. Contribution of Performance Appraisal to other HRM Practices (Edited by author)

With reference to Japanese management style, this specifically impacts two HRM practices. Typically, most Japanese companies do not have clear job descriptions and job specifications due to frequent job rotation. Each employee is expected to accept any work assigned to him or her by the company. This situation poses certain difficulties in designing an appropriate appraisal system. This is important because the outcome of an appraisal serves as a guide in determining promotion and salary rates for an employee.

Additionally, traditional Japanese culture discourages individual performance and places importance on team contribution. This is an obstacle to the adoption of individual performance-based system.

Moreover, the majority of Japanese companies still maintain a "seniority-based" system, (which has long been linked to job security in Japanese companies), to decide the salary adjustment and promotion. In today's labor market, a lifetime of employment is not practical and can no longer be guaranteed. Employees expect to have a clear career path with remuneration based on their contribution. In the absence of such conditions, employees will leave and look for new opportunities. Therefore, performance-based pay systems need to be implemented in overseas subsidiaries. Most of the top management who are Japanese assigned from the Japan headquarters, who are accustomed to the traditional system. They therefore find it difficult to understand or accept a novel and foreign concept system in their overseas operation.

Although, several major Japanese companies have begun to adopt performance-based systems with results-based appraisal systems. In practice, they face difficulties in implementing a renovated system to evaluate their employees' performance. However, if JCCs are unable to adapt and instill an appropriate appraisal and compensation system, they will experience high labor turnover and poor motivation in overseas subsidiaries.

Third, most respondents from the manufacturing sector stated that expatriation should lead to "the improvement of local management" and "knowledge transfer". They expected that technology from headquarters would be subsequently transferred to overseas subsidiaries who would then further advance to a similar technical level. Similarly, a majority of respondents stated that the "skills and knowledge of expatriates" was the most important criterion for them to be selected to work overseas. Japan MNCs therefore ought to ensure that potential expatriates have sufficient technical skills and ability to transfer them to workers at the overseas companies. In addition, the concern for "skill in handling culture differences" illustrated a culture gap between expatriates and local employees. In order to eliminate this hurdle, expatriates should have a solid understanding of the related culture and local practices so as to quickly adapt to the local working environment.

Respondents from the service sector had different concerns. They stated that the purpose of expatriation should be for "the improvement of communication between headquarters and overseas subsidiaries". This implies that service companies are more sensitive to challenges experienced by local employees when they attempt to communicate with the Japanese headquarters, to make contact, to understand of the actual situations, and so on due to language barriers. 
Japanese MNCs therefore have to clearly explain to potential expatriates that that they will serve as a communication bridge between the headquarters and the overseas subsidiaries.

\section{Implications of Findings}

The primary objective of this study was to compare the differences of human resources (HR) strategy between Mainland China-based and Hong Kong-based Japanese companies, and asses the underlying factors associated with these differences. Limited capacity at JCCs headquarters e to provide full support to overseas operations is an obstacle to managing global business. The adoption of local management in overseas operation is necessary in the long run. Local talents of high caliber should not only be confined to working as top management in overseas subsidiaries, but also be assigned to different regions, including the headquarters (Figure 17). Therefore, MNCs should put in place a comprehensive plan for training and providing more opportunities to locals who would serve as valuable assets to the company.

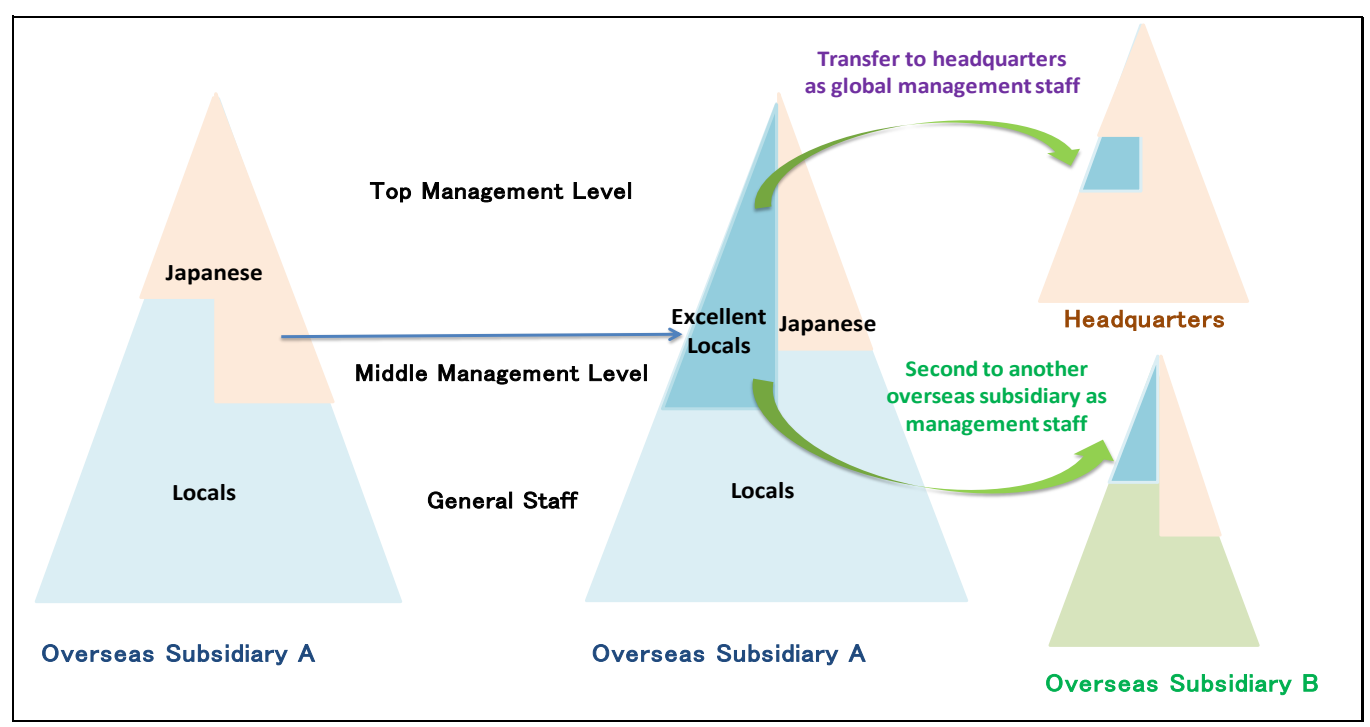

Figure 17. Promotion of Localization and Globalization of Excellent Employees (Edited by author)

Without a comprehensive assessment of common practices in overseas countries, Japanese expatriates will find it difficult to formulate effective remuneration plans and sound performance appraisal mechanisms. It is prudent to establish an enhanced global HR function at the headquarters that will coordinate and improve information sharing. This will then adequately equip potential expatriates for top management positions in overseas subsidiaries (see Figure 18).

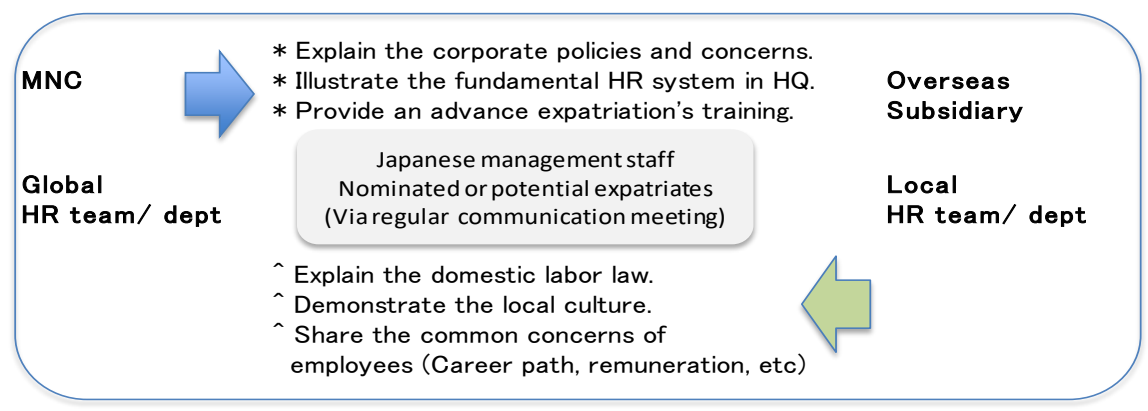

Figure 18. Information exchange of the local practice of employee compensation (Edited by author)

An assessment by industry, location, age, and size of companies provides an invaluable insight for formulating business strategies from a HRM perspective for Japanese MNCs. HRM concerns caused by an increase in demand for service companies in Mainland China are not confined to the JCCs in the service sector alone. Due to the increasing demand for labor in the service industries and decreasing demand for jobs in manufacturing businesses, difficulties in HRM issues may also be experienced in the current manufacturing sector as well. 


\section{References}

Alfes, K., Truss, S., Soane, E., Rees, C., \& Gatenby, M. (2013). The relationship between line manager behavior, perceived HRM practices, and individual performance: examining the mediating role of engagement. Human Resource Management, 52(6), 839-859. https://doi.org/10.1002/hrm.21512

Bartlett, C. A., \& Yoshihara, H. (1988). New Challenges for Japanese Multinationals: Is Organization Adaption Their Achilles Heel? Human Resource Management (1986-1998), Spring 1988, 27(1), P.19.

Beattie, V., \& Smith, S. J. (2010). Human capital, value creation and disclosure. Journal of Human Resource Costing \& Accounting, 14(4), 262-85. https://doi.org/10.1108/14013381011105957

Beechler, S., Bird, A., \& Raghuram, S. (1993). Linking Business Strategy and Human Resource Management Practices in Multinational Corporations: A Theoretical Framework. Advances in International Comparative Management, 8 , 199-215.

Bowen, D. E., \& Schneider, B. (1988). Services Marketing and Management: Implications For Organizational Behavior. Research in Organizational Behavior, 10, B. Stow, and L.L. Cummings, eds., JAI Press, Greenwich, CT. 1988.

Census \& Statistics Department. (2017). Census and Statistics Department, the Government of the Hong Kong Special Administrative Region. Retrieved from http://www.censtatd.gov.hk/site_map/index.jsp

Chu, C. M., \& Chen, D. H. (2007). Performance appraisal systems in service and manufacturing industries: evidence from Taiwan. Int J Manag 24(3), 512-521.

Deloitte Shanghai. (2013). Research report of fresh graduate in year 2013.

Dessler, G. (2011). Human Resource Management, Pearson. P.28-36, 656-677.

Goddard, J., Tavakoli, M., \& Wilson, J. (2015). Determinants of profitability in European manufacturing and services: evidence from a dynamic panel model. Appl Financ Eco, 15(18), 1269-1282. https://doi.org/10.1080/09603100500387139

Huang, T. C. (2001). The effects of linkage between business and human resource management strategies. Personal Rev., 30, 132-151. https://doi.org/10.1108/00483480110380316

IMF. (2012). People's Republic of China 2012: Article IV Consultation. IMF Country Report No. 12/ 195. Retrieved from http://www.imf.org/external/pubs/ft/scr/2012/cr12195.pdf

Izraeli, D. N., \& Adler, N. J. (1994). Competitive Frontiers: Women Managers in a Global Economy, Blackwell, Oxford.

Jackson, S. E., \& Schuler, R. S. (1995). Understanding Human Resource Management in the context of organizations and their environments. Annual Review of Psychology, 1995, 46, ProQuest Central, Pg. 237.

JBIC. (2012). Survey Report on Overseas Business Operations by Japanese Manufacturing Companies. Results of the JBIC FY2012 Survey:-Outlook for Japanese Foreign Direct Investment ( $24^{\text {th }}$ Annual Survey).

Jochen, L. (2002). Control and co-ordination of Japanese subsidiaries in China: problems of an expatriate-based management system. International Journal of Human Resource Management, 13(6), September 2002, 901-919. https://doi.org/10.1080/09585190210134273

Krishnaveni, R., \& Deepa, R. (2011). Sectoral Differences in HRM Practices of Coimbatore Industries. Pranjana, 14(1), Jan-Jun, 2011.

Larsen, P., Lewis, A., Brown, R., \& Tonge, R. (2006). Key features in the success of SMEs: a comparison of service and manufacturing firms. Ind Corp Chang, 21(5), 1255-1281. https://doi.org/10.1177/030630700603100303

Li, H., Wei, X. D., \& Xie, D. Y. (2009). Competitiveness of the Hong Kong economy. China Economic Review, 20 (2009), 573-586.

Luo, Y. (2001a). Determinants of local responsiveness: perspectives from foreign subsidiaries in an emerging market. Journal of Management, 27, 451-77.

Ma, C. (1998). Foreign-Funded Enterprises in China: The Difficult Task of Talent-Keeping and its Impact on the Wage Structure. JETRO China Newsletter, 132, 2-9.

Meyer, D. (2008). Structural Changes in the Economy of Hong Kong since 1997. The China Review, 8(1) (Spring 2008), 7-29.

NBS. (2017). China Statistical Yearbook, China Statistics Press, National Bureau of Statistics of China. Retrieved from http://www.stats.gov.cn/tjsj/ndsj/ 
Pfeffer, J. (1994). Competitive Advantage through People. California Management Review, Winter 1994.

Schneider, B. (1994). HRM - A Service Perspective: Towards a customer focused HRM. International Journal of Service Industry Management, 5(1), $64-76$.

Sengupta, K., Heiser, D. R., \& Cook, L. S. (2006). Manufacturing and service supply chain performance: a comparative analysis. J Supply Chain Management, 42(4), 4-15.

Stewart, J. B., \& Morrison, A. J. (2010). Sunset in the Land of the Rising Sun: Why Japanese Multinational Corporations Will struggle in the Global Future, Palgrave Macmillan.

Taylor, B. (1999). Japanese management style in China? Production practices in Japanese manufacturing plants. Japanese Management in China, 1999, New Technology, Work and Employment, 14(2).

Taylor, B. (1999). Patterns of Control within Japanese Manufacturing Plants in China: Doubts about Japanization in Asia. Journal of Management Studies, 36(6), 853-73.

The 21st Century China Research Institute (2013). Chugoku Sinshutsu Kigyo Ichiran, 2013-2014. Sososha

Ulrich, D., Brockbank, W., Younger, J., \& Ulrich, M. (2013). Global HR Competencies - Mastering Competitive Value from the Outside in, The McGraw-Hill Companies.

Wang, P. T. (2014). Goodbye, World factory, Prophet Press.

Wang, X. P., Li, S. M., \& Rao, M. (2007). East Asia Economic Cooperation in new century, China Review Academic Publishers Limited.

Wickramasinghe, V., \& Fonseka, N. (2012). Human resource measurement and reporting in manufacturing and service sectors in Sri Lanka. Journal of Human Resource Costing and Accounting, 16(3), 2012, Pg.235-252.

World Bank. (2013). China 2030: building a modern, harmonious, and creative society (English). Washington, DC:

World Bank. Retrieved from

http://documents.worldbank.org/curated/en/781101468239669951/China-2030-building-a-modern-harmonious-and -creative-society

\section{Copyrights}

Copyright for this article is retained by the author(s), with first publication rights granted to the journal.

This is an open-access article distributed under the terms and conditions of the Creative Commons Attribution license which permits unrestricted use, distribution, and reproduction in any medium, provided the original work is properly cited. 